\title{
Vepsa rahvameditsiini mõnest aspektist
}

\author{
Kristi Salve
}

Teesid: Artikkel põhineb olulises osas autori aastakümnete jooksul tehtud välitööde käigus kogunenud ainestikul. Lisaks on autor leidnud materjali trükistest, mis enamasti on keeleteadusliku iseloomuga: eeskätt tekstikogumikud, kuid ka uurimused, sõnaraamatud. Isegi ilukirjandus on andnud allikmaterjali. Muidugi on autor kasutanud ka rahvameditsiini-alaseid uurimusi - kahjuks on neid otse vepslaste kohta vähe, kuid võrdlusmaterjali pakuvad ka teiste rahvaste kohta kirjutatud tööd.

Üks artikli keskseid tõdemusi on vepsa rahvameditsiini suur elujõud veel 20. sajandi lõpus. Kuigi tihti on rahvaarstidest kõnelemise alguses nimetatud nende juurest abi otsimise põhjenduseks asjaolu, et "vanasti ju haiglaid polnud", on selliste avalduste taga pigem ettevaatus: võõrale ei taheta näidata, et vepslased on mahajäänud, harimatud jne, sest ametlik diskursus on seda just nii hinnanud. Tegelikult ei kasuta rahvaarstide abi ainult vanad inimesed, vaid ka nende lapsed ja lapselapsed kodukülas puhkuse veetmise ajal.

Huvitavad on rahvameditsiini ja akadeemilise meditsiini vahelised suhted vepsa külades 20. sajandi teisel poolel. Üldjuhul on rahumeelselt tööpõldu jagatud. Inimesed, kes küll kasutasid rahvaarstide abi, ei vastandanud seda akadeemilisele meditsiinile. Harvadel juhtudel, kui seda on tehtud, on enamasti peetud tõhusamaks just rahvameditsiini. Samas on viimaste sugupõlvede ajal arsti- (enamasti siiski keskastme meditsiinitöötajate) abi tänulikult ja ilma kriitikata vastu võetud. Süstimine ja tablettide võtmine on vanemate põlvkondade silmis peaaegu maagilised tegevused.

Vepsa rahvameditsiini elujõu konstateerimise kõrval on artiklis pööratud tähelepanu ka ravivõtete jagamisele ratsionaalseteks ja maagilisteks, mida etnoloogid-folkloristid sageli kasutavad. Sellise jaotuse produktiivsus 
tundub kahtlasena. Taimravi, massaaži jms esiletõstmine on pigem ideoloogiliselt põhjendatud, samas kui traditsioonikandjad seavad ühemõtteliselt esiplaanile loitse, palveid, pühitsetud vett ja muid selgelt uskumuslikul alusel olevaid võtteid. See on seotud asjaoluga, et ka haiguste etioloogia on valdavalt usundilise tagapõhjaga.

Võib eeldada, et kuni elab (praegu küll valdavalt pensionäridest elanikkonnaga) vepsa küla, on seal oma koht ka rahvameditsiinil ja -arstidel. Muidugi toimub muutusi ka 21. sajandil nagu eelnevalgi, ning nende jälgimine oleks edaspidigi vajalik.

Märksõnad: loitsud, rahvaarstid, rahvameditsiin, rahvausund, ratsionaalne ja maagiline, ravimtaimed, vepslased

\section{Sissejuhatuseks}

Vepsa rahvameditsiini on vähe uuritud - isegi veel vähem kui selle rahva vaimse kultuuri muid tahke. Selle lausega võib päris julgesti alustada veel mitut artiklit, sest väidetu jääb kehtima nii pärast käesoleva põgusa vaatluse kui ka mõne kaalukama käsitluse ilmumist. Kui vepsa rahvausundi uurimine on 21. sajandi esimese kümnendiga astunud üsna jõulisi samme monograafiate, koguteoste ja artiklite näol, siis rahvameditsiin on paremal juhul leidnud käsitlemist muu kõrval. Sealjuures on tegemist äärmiselt huvitava nähtusega.

Kõigepealt paar sõna sellest, mis on praeguseks kasutada vepsa rahvameditsiini kohta teadmiste ammutamiseks.

Vaadates üle tänapäevani vepsa keele ja rahvakultuuri kohta ilmunut, näeme, et trükiseid, millest võib leida mõnesugust allikmaterjali, on üsnagi palju ja valik on mitmekesine. Siia kuuluvad keelenäidete kogumikud, sõnaraamatud, etnograafilised kirjeldused, uurimused rahvakultuuri muudelt aladelt, kus rahvameditsiini puudutatakse möödaminnes, matkamuljed, isegi ilukirjandus jne. Kuigi vähe, leidub ometi ka spetsiifilisemaid väljaandeid. Esimesena peab kindlasti nimetama just rahvameditsiinile keskendatud publikatsiooni teenekalt Soome vepsa-entusiastilt Jussi Rainiolt. Materjalipublikatsioonina on see hindamatu väärtusega usaldusväärsuse tõttu. Oma kirjapanekud on J. Rainio nimelt teinud Äänis-Vepsas koduses õhkkonnas oma ämmalt (Jussi Rainio oli Teise maailmasõja ajal abiellunud vepsa neiuga) ja selle õdedelt, kellele ta oli omainimene (Rainio 1973). Teises rahvameditsiinispetsiifilises artiklis on Petroskoi uurijad Irina Semakova ja Valentina Rogozina (Semakova \& Rogozina 2006) tuginenud ühelt poolt suurte teenetega tandemi Maria Mulloneni ja Maria Zait- 
seva tekstikogumikule ja sõnaraamatule (Zaitseva \& Mullonen 1969; Zaitseva \& Mullonen 1972), kasutades neis leiduvat meditsiinialast teavet, teiselt poolt ka iseeneste poolt erinevatelt vepsa murdealadelt kogutule. Nagu selgub, on kogutud ja tõenäoliselt 20. sajandi viimastel aastakümnetel talletatud materjal vägagi huvipakkuv. Artiklis on tutvustatud ravimtaimi, antud ülevaade terminoloogiast ning vaadeldud paljude haiguste põhjusi ja raviviise. Suurel osal viimastest on uskumuslik alus. Päris loomulikuks võib pidada asjaolu, et lüheldases artiklis pole jagunud ruumi rahvaarstide iseloomustamiseks, samuti jääb puudutamata küsimus rahvameditsiini vahekorrast n-ö kooli- või akadeemilise meditsiiniga. Madis Arukase käsitlus (Arukask 2009) lähtub seevastu just konkreetsest rahvaarstist, keda ta on koos oma välitöökaaslase Taisto Raudalaineniga intervjueerinud ja püüdnud avada tema mõttemaailma. Tema käsitlus on J. Rainio ning I. Semakova ja V. Rogozina publikatsioonide otsese vastandina tugevalt teoreetilise kallakuga.

Loodan niisiis, et minu järgnev käsitlus suudab senistele ometi midagi lisada. Selle aluseks on suures osas mu enda rohkem kui kolmekümne aasta jooksul vepslaste seas tehtud välitööde käigus talletatu, mis pole alati helisalvestatud, vaid kirja pandud tagantjärele ja konspektiivselt märkmevihikusse või ka ainult mällu jäädvustunud asjakohased katked loendamatutest tutvumis- ning tee ja teadjate järele küsimise vestlustes - olgu siis külatänaval, poes, Vidla bussijaamas, surnuaias või muudeski paikades. Ka juba kellegi kodus teelauas istudes pole pikemast küsitlemisest-salvestamisest erinevatel ja värvikatelgi põhjustel alati asja saanud, aga midagi huvipakkuvat möödaminnes kõrva taha panna on siiski leidunud. Arvan, et just see väga paljude inimestega suhtlemisel kogunenud killukestest kokku pandud mosaiik võimaldab ehk konkreetsete ravivõtete kõrval näha üldisemat ja põhimõttelisemat. Küsimused, mis mulle kõige suuremat huvi pakuvad, on esiteks see, kas ja kuivõrd on rahvameditsiini uurijate vastandus maagiline - ratsionaalne ülepea relevantne; ja teiseks see, kuidas on pärimuslik ja akadeemiline meditsiin aastakümnete viisi kõrvuti toimides teineteisega arvestanud ja kohanenud.

Loomulikult olen lisaks kogutule kasutanud arhiivides ja kirjanduses leiduvat ainestikku. Varasemad kirjapanekud ja publikatsioonid annavad enamasti napi ja neutraalse pildi ühe või teise haiguse vastu kasutatud ravivõtetest või ka ennetavatest abinõudest. Pliiatsit ja paberit kasutanud koguja, kui ta eesmärk oli pealegi keelelise ainestiku fikseerimine, arvatavasti ei huvitunudki eriti jutustaja hinnangutest 
haiguste ja rahvaarstide kohta, pidades neid ennakult harimatu rahva ebausuks. Kindel on aga ka jutustajate suurem valmidus kõnelda usundiliselt neutraalsematel teemadel. Muidugi oli pikemate parandamislugude üleskirjutamine ka aeganõudev, kuid samas tuleb möönda, et pikki pulmakirjeldusi ja muinasjutte ometi saadi kirja panna. Nii või teisiti, aga varasemates väljaannetes võib küll leida loitsutekste (nt Setälä \& Kala 1951 näitetekstide kogu sisaldab neid 12 , sealjuures mitte ainult arstimisloitse), aga mitte lugusid nende kasutamisest, nendega kaasnevatest toimingutest ja konkreetsetest parandamisjuhtumitest kõnelemata.

Loomulikult sisaldavad isegi napi lause pikkused näited sõnaraamatus või keeleteaduslikus uurimuses (nagu Kettunen 1943) väärtuslikku, vahel isegi ainukordset teavet. Samas võime kõige uuema, ka mu enda helisalvestatud, kirja pandud ja meelde jäetud materjali põhjal lisaks ravimisviiside kirjeldusele näha põdejate ja parandajate hoiakuid üksteise, aga ka kõrvaliste isikute (nt kaugelt tulnud koguja) suhtes, samuti täheldada mõttelaadi püsimist ja muutumist. Mõnelgi juhul saab ka varasemaid nappe teateid interpreteerida hilisemate konteksti andvate teadete valguses.

\section{Rahvameditsiin ja akadeemiline meditsiin}

Järgneva käsitluse esimene eesmärk on välja selgitada uue ja vana, teisisõnu akadeemilise ja rahvameditsiini suhted, nende võimalikud konfliktid, aga ka kokkusobivus või -sobitamine. Tähelepanu keskmes on patsient, kes seisab justkui teelahkmel, kus üks viit osutab haigla, teine rahvaarsti suunas. Seoses sellega kerkib paratamatult üldisem probleem, mis on olnud vaatluse all eelnevateski vepsa, aga samuti teiste rahvaste rahvameditsiini puudutavates töödes.

Küsimus on mõiste rahvameditsiin defineerimises, mis võib mõnel juhul olla vägagi komplitseeritud. Vepsa ainestik sobib siinkohal tänuväärseks taustsüsteemiks kasvõi eesti rahvameditsiini määratlemisel.

Ave Tupits-Goršič on oma doktoritöö (2009) esimese peatüki pühendanudki mõiste "rahvameditsiin" määratlemisele Eesti ning mitmete Põhja- ja Kesk-Euroopa maade teadusloos. Esmapilgul näib asi olevat lihtne: rahvameditsiin vastandub akadeemilisele ehk koolimeditsiinile. Aga lähemal vaatlusel tuleb ilmsiks, et asi on keerulisem: akadeemiline meditsiin ise on tugevalt teisenenud sellest ajast peale, mil meil ja muudes riikides hakati rahvameditsiini vastu teaduslikku 
huvi tundma ja sellealast ainestikku koguma. Mõnedki ravivõtted on tollasest akadeemilisest meditsiinist kadunud, kuid vahepeal esialgu trükisõna kaudu ja lõpuks ka suuliselt edasiantuna - rahva seas tuntuks ja kasutatavaks saanud. Samas on meil Eestis eriti 1980. aastatest peale, osalt varemgi, levinud sellised ravisuunad, nagu nõelravi, homöopaatia jne, mis on ühtviisi võõrad nii eesti pärimuskultuurile kui ka ülikoolides õpetatavale arstiteadusele. Võib-olla võiks alternatiivmeditsiini mõiste hõlmata kõiki neid suundi, mis ei kuulu rahva- ega ka akadeemilise meditsiini valda? Teine võimalus oleks käsitleda alternatiivmeditsiinina muude alternatiivide kõrval ka traditsioonilist rahvameditsiini. Ilmne on, et määratlus peab lähtuma konkreetsest kultuurist (vt Tupits 2009).

Eesti rahvameditsiini uurijate seisukohalt hägustab pilti kindlasti asjaolu, et juba 19. sajandi algupoolest hakati avaldama mitmesuguseid "häda- ja abiraamatuid", "kodutohtreid" ja muid "lühikesi õpetusi", mille autorid olid ülikooliharidusega arstid, kes püüdsid nende kaudu maarahvast õpetada tarvitama õigeid raviviise ja rohtusid, hoidmaks neid posijate, st rahvaarstide poole pöördumast (Kõivupuu 2000). Mõnedki neist väljaannetest pärinevad ravivõtted võivad Eesti Rahvaluule Arhiivi kogudesse jõudnuna tekitada nõutust, sest esiteks on need algselt trükisõnast pärinevad õpetused sageli läbinud suulise leviku faasi, teiselt poolt aga võib leiduda selgeid viiteid kirjanduslikule päritolule. Sisult on nad tänapäeva meditsiini suhtes alternatiivsed, kuid kas üksnes sellepärast on tegemist rahvameditsiiniga? Paljudel puhkudel aktsepteeritakse kõiki rahvaluulearhiivis leiduvaid ravivõtteid ikkagi rahvameditsiinina ja nad leiavad end juba teise põlvkonna käsiraamatute lehekülgedelt. Alates viimasest sajandivahetusest, kui trükisõnale on lisandunud lõpmatult palju elektrooniliselt jagatavat materjali tervise, haiguste ja ravimise kohta, on piiri veelgi keerukam tõmmata. Inimeste ja ideede vaba liikumine on viinud selleni, et uute gurudega saabuvad uued õpetused ja praktikad, kerkivad kohalikud järgijad, kujuneb kogukond - aga kuniks? Nagu uus nutitelefon on parem kui vana, nii on parem ka uus terviseõpetus. Kõige selle taustal mõjub Eestis ussiviin (Kohler 2012) juba tõeliselt arhailise rahvameditsiini näitena, kuigi ei saa tegelikult olla vanem kui viinapõletamine ega vasta ka sellele kuvandile, mis on loodud esivanemate iidsest tervendamiskunstist.

Vepslaste puhul on pilt sedavõrd selgem, et neil võib n-ö tõelist, st pärimuslikku rahvameditsiini tänapäevani pidada koolimeditsiini ainsaks tõsiseltvõetavaks alternatiiviks, vähemalt vepsa külaühis- 
konna osas.Võib-olla on mingit mõju avaldanud raadiosaated, mis on jälgitavad translatsioonivõrgu kaudu arvatavasti kõigis vepsa külades, 20. sajandi lõpukümnenditest alates ka televisioon. Hakati ju Mihhail Gorbatšovi algatatud uuenduspoliitika mõjul massimeedias kõnelema ka seni mahavaikitud nähtustest, mõttesuundadest ja inimestest, kaasa arvatud selgeltnägijad, ime(rahva)arstid jt. Selliseid saateid vaadati/kuulati, neist kõneldi ja nende üle arutleti, kuid mulle näib, et need tugevdasid pigem usku oma pärimuslikku mitteakadeemilisse meditsiini. Teine asi on see, millega on kokku puutunud Peterburis või kasvõi Podporožjes elavad vepslased. Et esimese ja teise põlvkonna linlaste side kodukülaga on vägagi tihe, tasuks muidugi eraldi vaatluse alla võtta ka nende vaated rahvameditsiinile. Samuti äratab huvi, kas nad on võinud vahendada linnaühiskonnast saadud mõjutusi, nagu mitmesugused (vähemalt vepslaste silmis) mittetraditsioonilised alternatiivmeditsiini suunad. Olemata sellesuunalisi sihipäraseid küsitlusi teinud, on vestluste käigus kodukohta külastavate linnavepslastega ometi välja koorunud tõsiasi, et usk külades praktiseeritavasse rahvameditsiini on väga tugev ning linnaelu pole pannud sellele ülevalt alla vaatama. Muidugi tuleb arvestada, et Podporožje linn ise on hiline nõukogude võimu sünnitis ja selle elanikud väheste eranditega pärit küladest, olgu vene või vepsa omadest, või siis nende endiste külaelanike lapsed. Ka Peterburi, suure ja kuulsa kultuurikeskuse vepslastest elanikud ei ole liikunud akadeemilistes ringkondades, vaid ikka kutsekoolide-ühiselamute-uusasumite tüüpkorterite subkultuuris.

Linnavepslaste, olgu Podporožje, Lodeinoje Pole, Petroskoi või Peterburi omade, side kodukülaga oli mitut moodi tugev kogu nõukogude aja vältel ja ka pärast seda. Üks sidemete hoidjaid oli majanduslik huvi. Nõukoguliku kaubapuuduse tõttu oli linnas elavale noorele perele oluline see kartulitest, sibulatest, seentest ja marjadest koosnev talvemoon, mida vanematekodust võis saada ja saadigi. Lähemal asuvatel omastel oli võimalik sagedamini ja odavamalt kodus käia ning viia kaasa ka piimasaadusi (koduvõid ja kohupiima), aga teisalt aktiivselt abistada aiamaal ja heinamaal. Selline toidumajanduslik sõltuvus suurendas kahtlemate emade ja vanaemade autoriteeti, muuhulgas ka haigusi ja arstimist puudutavates küsimustes. Vepslaste toidumajandust N Liidu lõppaegadel ja postsotsialistliku perioodi alguses ning vastavaid ühiskondlikke suhtevõrgustikke on jälginud Kaija Heikkinen, kes on ka esile toonud naiste usundilise autoriteedi tulenemise nende halduses olevatest toiduressurssidest (Heikkinen 2006). 
Arvestades naiste arvulist domineerimist vepsa külades vähemalt Teise maailmasõja aegadest võibki öelda, et usk rahvameditsiini ja selle spetsialistidesse on kandunud emadelt tütardele. Üldjoontes samuti on kulgenud teadmised haigustest, nende põhjustest ja raviviisidest. Ühe usutletu vastus küsimusele, mida tehakse kadunud looma leidmiseks, kõlas nõnda: "Nagu tegid meie vanemad, nii teeme ka meie" (Salve 1995). Ja tõepoolest, kui veel 21. sajandi algul kasutati selleks kontakti loomist haldjatega ja nende käest kadumaläinu tagasiküsimist (Salve 2005; Arukask 2009), siis seesuguse mentaliteediga kooskõlas käib ka haiguste parandamine "nii, nagu tegid meie vanemad". Sõnasõnalt ütleski üks Ladva naine: Kut miile nevoiba, muga radame (nagu meid oppetati, nii me teeme).

\section{Ende ved boĺnicaid iilend}

Alapealkirjaks tõstetud lauset (eesti keeles: ennevanasti ju haiglaid ei olnud) olen kuulnud kümneid kordi, kui jutustajad on rääkinud omaenese või lähedaste haiguste ja parandamise lugusid. Osalt on see kõlanud kui rahvaarstide abi kasutamise siiras põhjendus. Tavaliselt on seda peetud vajalikuks siis, kui olin esitanud otsese, kuid samas üldise küsimuse vestluskaaslasele tema teadmiste kohta rahvaarstidest, et siis jutu hargnedes jõuda ehk tema isiklike kogemusteni parandajate juures käimisest, selle tõhususest jne. Minevik huvitas mind muidugi ka, kuid samas aitas kaugemalt alustamine vabamalt kaasajast kõnelema hakata.

Muidugi tuleb möönda, et päris ühemõtteline see ende-määratlus pole. See võib tähendada tõesti nii kunagist kuuldud minevikku, seega vanemate ja vanavanemate aega, aga ka iseenese lapsepõlve. Minu vanimate informantide põlvkond oli sündinud 19. ja 20. sajandi vahetusel, seega oli neil oma vanemate ning vanavanemate juttude järgi teadmisi ka 19. sajandi lõpupoolest. Mõnigi kord on aga jutuajamise kulgedes välja koorunud tõik, et ravitseja juures on käidud alles mõne aasta eest lapselapse või iseenese tervisehäda pärast. Niiviisi võib ende tähistada tõesti inimea seisukohalt kauget minevikku, mis on võrreldav muinasjuttude alguvormeliga ende eliba $u k$ da ak (ennevanasti elasid eit ja taat), kus ende võib varianditi puududa - oluline on, et eit ja taat elasid, sest kuidas muidu pääseksime jälgima nende kolme poja seiklusi! 
Teatud mõttes võib aga niisuguses rahvameditsiini eeskätt või üksnes minevikuga seostavas ütluses tabada kaasakõlamist progressiusuga: sellega mööndakse, et rahvaarstide, nõidade ja teadjate abi kasutamine polnud võib-olla eriti arukas, aga samas oli see paratamatu, sest alternatiivi ju polnud. Lähimineviku ja tänapäeva praktika taustal tundub, et see pole sisemine veendumus haiglate paremuses, pigem peitub selliste ütlemiste taga enesekaitsetaktika, sest ega vepsa inimenegi taha olla arenematu, mahajäänud, tagurlik - terminid, millega nõukogude ajal stigmatiseeriti inimesi väga erinevatel põhjustel. Kogu Euroopas levinud progressiusk oli Venemaal omandanud kommunismiusu näo. Selle usu kohaselt arvati kaduvat vepslastegi seas rahvaravitsejate poole pöördumine sedamööda, kuidas kerkivad haiglad. Niisugust vaadet jagas näiteks esimene vepslaste endi seast võrsunud etnoloog S. Makarjev, kes just nii kirjutaski (Makarjev 1931). Haiglad (sagedamini medpunktid) kerkisidki aegamööda. Mõnda neist, näiteks lõunavepsa alal Pölos kiriku ja surnuaia kõrval paiknenut, on nüüdseks tabanud kirikute kurb saatus. Olulisemat osa kui külas toiminud/toimivad medpunktid on arstiabi kättesaadavusel mänginud siiski palju hiljem (20. sajandi viimastel aastakümnetel) paranenud teeolud, mis on võimaldanud juurdepääsu suuremates keskustes paiknevatele raviasutustele.

Võib nentida, et n-ö valgustus, mis laskis rahvaravitsejaid ja nende teenete kasutajaid marginaliseerida - ühtesid petiste, teisi rumalate või vähemalt arengus mahajäänutena -, muutis vepslasi ehk teatud perioodil pisut ettevaatlikumaks oma asjakohaste teadmiste ja kogemuste avaldamisel, aga pole suutnud oluliselt mõjutada nende käitumist.

Samas ei saa ka öelda, nagu oleks viimaste põlvkondade kohustuslik kooliharidus, niivõrd-kuivõrd seda rakendati (1920.-1930. aastatel jäi osa lapsi koolist varakult kõrvale, aga eriti puudulikult toimis koolikohustus sõja- ja sõjajärgsetel aastatel, nii et veel 21 . sajandi hakul võis kohata kirjaoskamatuid), lausa mööda külgi maha jooksnud.

Minu poolt 1970. ja 1980. aastatel kohatud vanemad põlvkonnad olid sündinud enne Esimest maailmasõda, nüüdseks on nad läinud maha magadamha. Üldiselt olid need põlvkonnad koolihariduseta ja kehva vene keelega. Praegused vanimad elanikud on sündinud maailmasõdade vahel, väheste eranditega on neil vene keel ladusalt suus ja nad on, samuti väheste eranditega, kirjaoskajad. Järgmine, praeguseks samuti pensioniikka jõudnud põlvkond, kes on sündinud 1940.1950. aastatel, on juba kakskeelne ja julgem kasutama ametlikult 


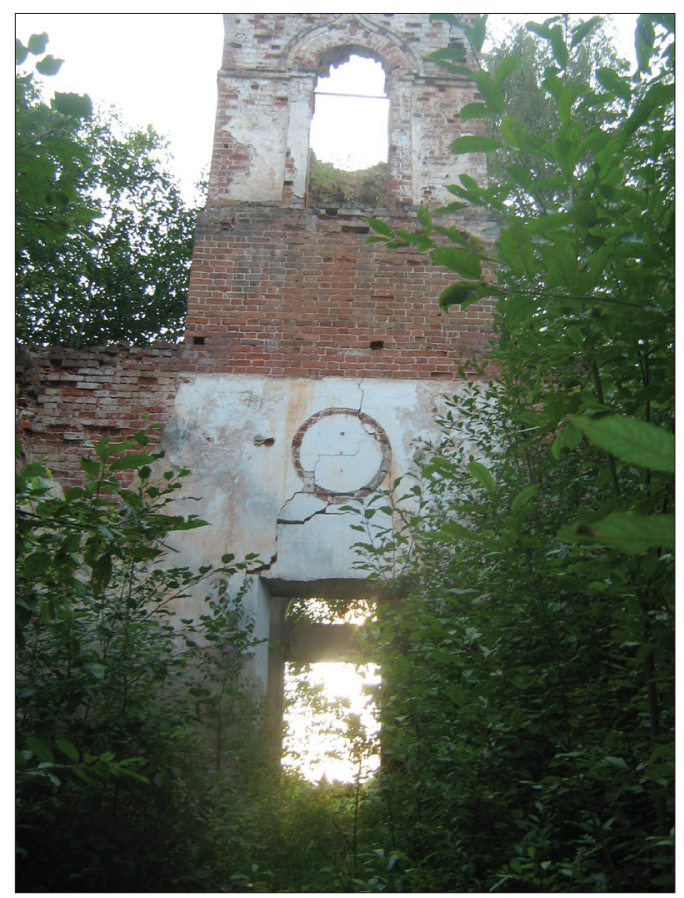

Foto 1. Pölo kiriku varemed. Siin, lõunavepslastele tähtsas kohas oli omal ajal ka kohalik haigla. Eva Saare foto 2014.

pakutavaid meditsiiniteenuseid kodukülast kaugemal. Nagu eespool nimetatud, olid suures osas vepsa küladest keskastme meditsiiniabi (velsker või õde) pakkuvad punktid, mida patsientide seas nimetati bolnic (haigla). Nendes käis muude hulgas ka 20. sajandi esimestel kümnenditel sündinute põlvkond. Võiks öelda, et selliste medpunktide ukselävi oli madal: velsker või õde oli sageli vepsa päritoluga ja omakeelne, ka õppisid kauemaks külla jäänud kohaliku noormehega abiellunud vene neiud ära vepsa keele ja muutusid omainimesteks. Viimastel, Nõukogude Liidu lagunemise järgsetel aastakümnetel on suur osa külade medpunktidest tegevuse lõpetanud. Ühelt poolt on põhjuseks elanikkonna jätkuv vähenemine, teiselt poolt juba mainitud paranenud ühendus suuremate keskustega. Kindlasti on vepslaste tervis selle tulemusena praegu paremates kätes kui põlvkond varem. 
Kuigi nn haiglad ei suutnud toona rahvaarste kõrvale tõrjuda ega isegi nende autoriteeti kahjustada, saavutasid nad ometi külades kindla positsiooni. Neisse suhtuti ja suhtutakse lugupidamisega ning nende teenuseid tarbiti täie usuga. Ma pole peaaegu kohanud kahtlusi ega kriitikat määratud ravi õigsuse suhtes. Võiks lausa öelda, et ametlikku ja rahvameditsiini suhtutakse võrdselt, sest ka viimast ei arvustata.

Olen ainult erandjuhtumitel kuulnud arstide suhtes kriitilisemaid seisukohti, needki kuuluvad 20. sajandi vahetusse lõppu ja 21. sajandi algusse. Minu meelest johtub see tõigast, et selleks ajaks olid küpsesse ikka jõudnud inimesed, kelle jaoks oli akadeemiline meditsiin olemas olnud lapsepõlvest saadik, nad olid sellega harjunud ja valgetel kitlitel polnud nende silmis erilist aupaistet. Loomulikult on oma mõju olnud ka üldistel vabadusmeeleoludel, kui ühtäkki tohtis hakata kõnelema kasvõi sellisest aastakümneid mahavaikitud teemast nagu nõukogude võimu kuriteod. Minu vepsa välitööde algupoole 1970.-1980. aastatel oli inimeste hirm nii suur, et väga tihti ei tahetud rääkida ka rahvameditsiinist palju vähem sensitiivsetel teemadel, ning kui heast südamest seda siiski tehti, kaheldi pärast: Minä ńevoin, a voib olda jälghe türmha putun (ma jutustasin, aga võib-olla pannakse pärast vangi).

Inimesed, keda olen küsitlenud, on üle elanud raskeid aegu: kolhooside moodustamisele eelnenud, sellega kaasnenud ja järgnenud repressioonid, sõjad, sundvärbamised. Allesjäänute (peaasjalikult naiste ja laste) osaks sai üle jõu käiv töö ja pidev nälgimine. Naised olid enamasti ilmale toonud palju lapsi, kellest mõnedki surid esimestel eluaastatel kas alatoitlusest tingitud haigustesse või lausa nälga. Nü̈gud eläda olnuiž čoma, a kolda tariž (nüüd oleks hea elada, aga peab surema), on kahetsevalt öeldud. Pole ime, et kõigest sellest läbi tulnute füüsiline seisund oli halb. Hädas haaratakse üldiselt kõige järgi, kust abi loota, nii jagunes ka tööpõld akadeemilise ja rahvameditsiini vahel, kusjuures pidevalt on ette tulnud ka dubleerimist. Arenes välja omamoodi integreerunud kooslus. See ei tähenda üksnes samas külas või asulas üheaegselt tegutsevaid ametlikke meditsiiniasutusi ja rahvaarste, kusjuures esimesed on viimastest vägagi teadlikud. Tegelikult ei toimunud integreerumine üksnes füüsilises ruumis, vaid ka mentaalses sfääris. 


\section{Ratsionaalne ja maagiline}

Kui akadeemilist meditsiini peaksid iseloomustama tõestuspõhisus, st registreeritud vaatlused-katsed ja nende põhjal tehtavad loogilised järeldused, siis alternatiiv, antud juhul rahvameditsiin, oleks uskumustel põhinev ja traditsioonile toetuv. Teisisõnu ja lühemalt öeldes oleks tegemist ratsionaalse ja maagilise vastandamisega. Toodud vastepaar on olnud kasutusel nii vepsa kui ka teiste rahvaste rahvameditsiini puudutavates töödes. Vepsa rahvameditsiini lähem vaatlus allpool näib pigem sinnapoole kalduvat, et mõlemad mõisted võiks erapooletuse huvides esitada jutumärkides, niisiis näiteks "ratsionaalne" rahvameditsiin ja "maagiline" akadeemiline meditsiin. Niimoodi mööname iseendagi vaadete ja hinnangute subjektiivsust ja näitame soovimatust pretendeerida viimase instantsi tõe valdamisele. Omaette küsimus on muidugi see, mis on uurijaid suunanud sellist eristust taotlema. Mõningaid vastuseid on järgnevalt ka pakutud.

Just mu vepslastest informantide suhtumine haigustesse ja ravimisse-tervendamisse, nagu see avanes spontaansetes mõtteavaldustes ja sihipärase küsitlemise vastustes, sundis mind põhjalikumalt mõtlema ülalosutatud vastandusele rahvameditsiini käsitlustes. Tähelepanu väärib tõik, et kuigi ratsionaalsust on peetud akadeemilise ehk koolimeditsiini põhijooneks, on seda väga üldiselt püütud leida ka rahvameditsiinis. Nõukogude perioodil ja hiljemgi toonasest mõtteviisist mõjutatute puhul on üks sellise suundumuse põhjusi asjaolu, et tollase dogma kohaselt oli rahvale omane stiihiliselt materialistlik mõtteviis. Selle dogma esmane rakendus oli ateistlikus propagandas, kuid selle raames oli hea ka näidata, et rahvas ravis haigusi vastavuses materialistliku paradigmaga: ravimtaimedega, massaažiga jne. Teine põhjus, mis on kallutanud ja kallutab uurijaid poolvägisi ratsionaalsust otsima, on hirm osutuda omamoodi kultuuriimperialismi kandjaks. Paraku on leitud ratsionaalsus mõnigi kord väga kahtlase väärtusega.

Nii on Piret Raud (1975) oma Djorža karjalaste rahvameditsiinile pühendatud artiklis jaganud rahvameditsiini võtted kahte liiki, millest esimesed on kogemusel põhinevad ja seega ratsionaalsed, teised maagial põhinevad.

Marju Kõivupuu (2000) on oma rahvameditsiini võtete liigituses toonud samuti välja ratsionaalsed, kuid ülejäänute seas eristanud veel ebaratsionaalseid raviviise maagilistest. Esimesed on tema seisukoha järgi sellised raviviisid, mille puhul on tegemist mingi materiaalse va- 
hendiga, nagu klaasipuru ja elavhõbe, mille kasutamine võib osutuda patsiendile eluohtlikuks, maagiliste alla kuuluvaks peab ta sõnadega arstimist, mis sellist ohtu ei kätke.

Kaugematest soome-ugri rahvastest vepslastega mitmes mõttes võrreldavate komide rahvameditsiini uurija Irina Iljina hindab izvakomide rahvameditsiini vägagi ratsionaalseks. Samas sarnaneb tema poolt lähemalt vaadeldud rahvaarsti puudutav pärimus vägagi vepslaste või ka eesti nõidarstide pärimusega, näiteks motiiv sellest, et ravitseja teab juba ette, mispärast tema juurde tuldi, ta ei võta raha, kuid kingitusi siiski, kitsidus või sobimatu käitumine tema suhtes leiavad karistamist jne (Iljina 2008).

Vepslaste kultuuriga ühisjooni omavate Äänisjärve-taguste venelaste perekonnatavandeid ja uskumusi käsitledes leiab Konstantin Loginov ühe spetsiifilise väikelastehaiguse puhul rakendatud ravivõtete puhul, et mõnedes ravivõtetes esinesid "ratsionaalsed elemendid", pidades ülejäänuid müstilisteks ja maagial rajanevaiks. Teise haiguse puhul nendib ta, et "ainuke ratsionaalne" raviviis oli rukkilillede ja ühe teise taime keedus, kõik ülejäänud olid irratsionaalsed (Loginov 1993: 91, 92). Viimasest näitest ilmneb väga kujukalt tendents pidada taimravi a priori ratsionaalseks, küsimata, mida ütleksid konkreetse taime kasulikkuse või kahjulikkuse kohta professionaalid.

Huvitav ja õpetlik niisuguse suundumuse tõestuseks on asjaolu, et Maria Mullonen ja Maria Zaitseva on oma tekstivalimiku ühe osa pealkirjastanud kut spravitadas ličindhiinil (kuidas arstitakse ravimtaimedega) (Zaitseva \& Mullonen 1969: 284-288), kuigi kirjeldustes on taimede kõrval juttu ka muudest ravivõtetest, sealhulgas maagilistest. Ka Irina Semakova ja Valentina Rogozina alustavad oma artiklit (2006) vepslaste seas tuntud ja kasutatud ravimtaimede ülevaatega, kuigi põhiosa artiklist on pühendatud ravimisele sõnadega ja/või maagiliste tegevustega ning ka pealkirjas osutatakse "mütoloogilisele aspektile". Ilmselt mõjutas sellegi töö autoreid (ehk isegi teadvustamata) seisukoht taimravist kui "tõelisest" ja "heast" rahvameditsiinist, mis vastandub ebausul põhinevale sõnadega arstimisele.

Võib küll täie kindlusega väita, et rahvameditsiini võtete jagamine maagilisteks ja ratsionaalseteks, samuti irratsionaalseteks ja ratsionaalseteks on uurijate konstruktsioon. Rahvaravitsejate ja nende abi kasutajate käsitused ei anna sellele tuge, nagu näeme vepsa materjali põhjal, aga muidugi on tegemist üldise olukorraga. Loomulikult on uurijail õigus ja vajaduski luua oma konstruktsioone, kui see aitab kaasa käsitletava ainestiku mõistmisele, aga seda tehes 
peaks jaguma tarkust hoiduda oma ajastu käibetõdedega tegelikku pilti moonutamast.

Heitkem kriitiline pilk neile juurdunud kujutelmadele, mis käivad rahvameditsiini n-ö ratsionaalse poole kohta. Paratamatult tulevad esimestena meelde Eesti minevikus ja olevikus käibinud vaated kui kõige tuttavamad. Taustsüsteemina sobivad nad ka vepsa rahvameditsiini vaatluseks.

Nagu teada, tegutseb Eestiski hulgaliselt isikuid, kes nimetavad ennast teadmameesteks ja -naisteks, sensitiivideks vms, kes telefoni teel alandavad vererõhku ja panevad astraalkehasid paika, vabastavad alkoholismist, võtavad ära needust ja suurendavad naiste rindu, ennustavad majanduslangust ja tuntud inimeste eraelu. Neist kirjutavad isikulugusid tähtsad päeva- ja nädalalehed, kõnelemata juba arvukatest naiste-, pere-, kodu-, esoteerika jm ajakirjadest ja internetist. Nad on meediapersoonid, avaliku elu tegelased, kes naudivad tähelepanu. Neid on mõlemast soost ja erinevas elueas: kenad noored naised, hoolitsetud küpses keskeas prouad, rohkem või vähem alternatiivsete riietumisstiilidega isandad.

Minnes tagasi lähiminevikku, traditsioonilise rahvameditsiini juurde, näeme arhiiviainestikust samuti, et taimravi oli pigem marginaalne. Markantsete Lõuna-Eesti Suride ravivõtete arsenalis kuulus tähtsaim koht sõnadele, millele lisaks kasutati raudnaelaga segatud vett ja muid substantse. Ainult poja puhul on üksikjuhtumitel nimetatud ka taimede kasutamist (Kõivupuu 2000).

Samas on tänapäeva eestlastele üldiselt tuttav ettekujutus rahvaravitsejatest, memmekestest, kes elavad kusagil talu saunakambris, mis on täis riputatud kuivatatud taimede lõhnavaid kimpe, kelle juures käiakse abi otsimas haiguste vastu ja kes annavad hädalistele keediseid, leotisi, salve. Muidugi ei taha ma väita, nagu olnuks taimravi olematu, üksnes osundan, kui varmad ollakse vastu võtma lihtsustatud, sageli dualistlikke ettekujutusi. Selline eideke oli ju läbinisti hea, tema helges kujus kehastus rahva iidne elutarkus.

Võhikuna kahtlustan, et selline taimi koguv, kuivatav ja leotav eesti eideke võib suures osas olla poolkirjanduslik-poolteaduslik konstruktsioon. Selle juured võivad peituda rahvusromantilises muistse kuldajastu ihaluses, püüdes näidata, et "sakste" suhtumine maarahvasse kui nõiduse ja posimise harrastajatesse on olnud väär ja ülekohtune.

Kirjanduses konstrueeritud parandajakuju vepsa näiteks sobib vene keeles kirjutanud Vassili Pulkini etnobiograafilises kirjutises "Azbuka detstva” (vt Pulkin 1985) esinev episood, kus vanaema ravib minatege- 
lase lõikehaava, seisates verejooksu silmavaatega. Niisugust vägevat silma pole pärimustekstides õnnestunud kohata. Silmavaatega võis (ja võib siiamaani) uskumuste kohaselt küll inimese ära rikkuda, ta haigestumist põhjustada, aga ravimiseks, sealjuures vere peatamiseks, pelgalt pealevaatamisest ei piisa. Sel juhul on appi võetud vastavad vere peatamise sõnad, mida on ka korduvalt talletatud. Ilmselt ei tahtnud autor oma vanaemale omistada posija toimimisviisi. Kuigi nõukogude aja ametliku maailmavaatega, mis pidi olema teaduslik materialism, pole ka V. Pulkini kirjeldus eriti kooskõlas, tundus see ilmselt siiski parem, "ratsionaalsem" kui loitsu lugemine.

Arvatavasti on samasugune "lihtsat" rahvast justkui rehabiliteerida püüdev hoiak täiesti olemas ka teiste rahvaste uurijate puhul. Kui kuulutakse uuritavatega samasse etnosesse, siis on mõistetav, et "meie" rahvaarste püütakse lähendada modernismiajastu ideaalidele, vastupidistel juhtudel, kus uurijad on teise, sageli võimupositsioonis oleva rahva liikmed, püütakse vältida võimalust saada süüdistatud üleolevas suhtumises.

Samas jäetakse tähelepanuta asjaolu, et tänapäevane akadeemiline meditsiin pole kuigi vana ja et veel Rootsi ajal Tartus õpetatud arstiteadus oleks pigem liigitatav irratsionaalseks. Kuna meil puuduvad konkreetsemad andmed muistsete tšuudide, vesside jm nime kandnud läänemeresoome rahvaste eelkäijate nõidarstide tegevuse kohta, siis pole ka võimalust kõrvutada seda nende kaasaegsete "kõrgklassi" arstide omaga. Selleks ajaks, kust pärinevad konkreetsed andmed vepsa, natuke varem aga eesti rahvameditsiinist, oli moodne arstiteadus alles suhteliselt hiljuti jõudnud tõhusate raviviiside rakendamiseni. Võib-olla johtus üleolev suhtumine rahvameditsiini kui posimisse, mis peatselt kaob hariduse valguse eest, ka moodsa meditsiini esimeste edusammude (võiks nimetada ohtlike nakkushaiguste võitmist vaktsineerimise abil, röntgeniaparaadi kasutusele võtmise kaudu saavutatud edu diagnoosimisel jne) joovastusest.

\section{Vepslaste tervis, haigused ja nende põhjused: terminoloogilist}

Vepsa sõnad terveh ja tervhuz (terve, tervis) on läänemeresoome päritolu. Nagu eesti keeleski, on selle inimese seisukohalt üliolulise mõistega seotud ka kohtumisel öeldav hea soov tervhen (tere, tänapäeva kõnekeeles küll suuresti venelaenulise tervituse ees 
taandunud). Huvitaval kombel on terveoleku vastandit märkivad sõnad läänemeresoome keeltes erinevate tüvedega, kusjuures vepsa keeles haigust, haige olemist ja haiget märkivad läžund, läžuda ja läžui (lähedased tüved esinevad ka karjala ja ingerisoome murretes) võiksid olla venelaenulised: vrd vene ležat (lamama). Samas vepsa keeles tähendabki verb läžuda ühtlasi 'lamada', mis on ju haigele iseloomulik olek. Omasõna lamamise tähenduses venuda on vepsa keeles samuti täiesti tarvitatav ning seegi väljend tähendab haigust. Kui näiteks kellegi kohta öeldakse, et ta čogas venub (nurgas lamab), siis tähendab see, et tegu on voodihaigega. Erinevalt eesti keelest on vepsa keeles verbil voida (võida) ka terveoleku ja eitusvormil seega haigeoleku tähendus. Kui vepsa kut void oleks (nagu ka soome kuinka voit) eesti keelde tõlgitav 'kuidas elad', siis niisuguste väljendite nagu ii voi (tähttäheliselt (tema) ei või) mõte on selles, et kõnealune isik on haige. $E m \_b o i$, em_boi (ma pole terve olen haige) - sellist kurtmist olen kuulnud sadu kordi. Enamasti on järgnenud täpsustused: Rungon kibištab, jougan porotab (Keha valutab, jalg lõhub valutada) või Läžun, kaik sijad kibedad! (Olen haige, kõik kohad on valusad). Nagu neist näidetest võib täheldada, on vepsa keeles tuntud ka vana läänemeresoome tüvi kibu (valu, haigus) koos tuletistega kibed (valus, kibe) (viimast vastet oleks ehk sobiv kasutada itkudes esineva püsiva sõnapaari kibedad kündled (kibedad pisarad) puhul) ja verb kibištada (valutada). Ka selline läänemeresoome keeltes üldlevinud haigustermin nagu taud on vepsa keeles esindatud, kuid tal pole spetsiifilist hävitava epideemia tähendust. Tavakasutusest taandununa esineb ta ainult liitsõnaliste haigusnimetuste järelkomponendina (pätaud peahaigus, nohu; pasktaud - pasataud, kõhulahtisus).

Samuti liitsõna järelkomponendina esineb haigusnimetustes $p a-$ gan - vezipagan, kilbetpagan, mecpagan (vesipagan, saunapagan, metsapagan). Sõna pagan on vepsa keeles laia tähendusväljaga, mille keskmeks võib pidada tähendust 'roojane, rituaalselt ebapuhas'. Sõna esikomponent näitab haiguse saamispaika. Enamasti kasutatakse neid nimetusi mitut laadi nahahaiguste kohta.

Kindlasti väärib märkimist epideemiana esinenud, sageli müütilisi konnotatsioone omava haiguse rõuged vepsakeelsed, läänemeresoomeliste (ka eesti murretes esineb rubid) vastetega nimetused rok ja paharubi.

Väga huvitav on usundiloolisest vaatepunktist haigustermin ičhiine, mis tähendab langetõbe, tõsi, mõned minu informandid on andnud sellele ise paralleelnimetuse paraliz, st halvatus, kuid see on 
ilmselt hiline tähendusmuutus. Ičhiine on tuletis sõnast iče (ise), mis kuulub muistsesse hingeterminite kompleksi. Minu vestluskaaslased pole teadnud midagi selle ravimisest või on koguni väitnud, et see ongi ravimatu.

Parandamise jaoks tarvitatav sõna spravitada on läbipaistvalt vene päritolu, konkreetselt on see seotud vene murdelise ispravit-sõnaga (SOS 0537). Tõsi, kasutusel on olnud ka omakeelne abutada, mille esmane tähendus on 'aidata', aga samuti pästta (päästa) või koguni rata (töötada, teha). Algselt ennustamist tähendanud arboida on omandanud ka (sõnadega) ravimise lisatähenduse.

Eeltoodu osutab tõsiasjale, et kesksed haigusterminid on vepslastel ühised lähemate keelesugulastega ja pärinevad järelikult ajast enne vene ekspansiooni. Konkreetsete haiguste ja nende ravimisega seotud sõnavara puudutan järgnevalt koos kõige muuga ohtude ja rohtude kaupa.

\section{Haiguste etioloogia}

Irina Semakova ja Valentina Rogozina annavad oma artikli alguses (2006: 304-305) lühikese loetelu haiguste põhjustest "informantide arvamuse kohaselt": raske töö, traumad, infektsioon, hügieenireeglite eiramine, organismi ealised muutused (vananemine). Julgen väita, et kuigi vepslaste koolis käinud põlvkondadele kahtlemata jagati teadmisi käte pesemisest kui nakkuse vältimise abinõust, oli käte pesemine enne sööki nagunii juba varem juurdunud, tingituna pigem kultuuritraditsioonist, mis taotles rituaalset puhtust ja väljendas lugupidamist toidu vastu. Kui autorite informandid tõesti sellist valgustatust ilmutasid, võis see olla vastutulek küsitlejatele. Minu informantidel pole nii- või teistsuguses infektsioonis probleemi olnud. Küll võiksin nende nähtud haiguspõhjusena nimetada külmetamist, mis võib ju akadeemilise meditsiini vaatenurgast olla seotud ka infektsiooniga.

Kui ülalnimetatud põhjusi pidasid I. Semakova ja V. Rogozina ilmselt (seda küll nimetamata) ratsionaalseteks, siis järgnevalt tulevad vaatlusele "religioossed-maagilised" haiguspõhjused. Aga naaseme veel eespool nimetatud raske töö juurde, mille tagajärjel arvati naba paigast minevat või "langevat". Halvemal juhul võis inimene selle tagajärjel surra, nagu väideti. Täpsustuseks võib lisada, et naba paigast mineku põhjuseks ei peetud ainuüksi rasket tööd. Aga olulisem on see, miks peeti mitmesuguseid sisemisi vaevusi seotuks just naba vale asendi- 
ga. Siin on selgelt mängus mütoloogiline mõtlemine: inimese nabale omistati eriline tähtsus. Naba oli keskpunkt, millest kõik lähtus, nii mikro- kui ka makrokosmoses. Neid seoseid on vepsa toponüümika põhjal avanud Irma Mullonen (1994, käesolevas kogumikus lk 227-236).

Näeme, et raskest, sageli tõesti inimvõimete piire ületavast tööst, mida omal nahal pidid kogema vepslaste vanemad põlvkonnad, saadud tervisehäda tõlgendati ometi usundilises võtmes.

Enamasti on vepsa traditsioonis käibel olnud palju avatumalt usundilisest mõtlemisest lähtuvad etioloogiad. Laias laastus võib haigestumise põhjused jagada kaheks. Esimesse rühma kuuluvad kannatanu enda süü - valdavalt normirikkumise - läbi tekkinud hädad. Täiskasvanu võib põhjustada ka oma lapse või looma haigestumise, kui tema eksimus tuleb nende peale. Arvestades vepslaste elavat haldjausku on ootuspärane, et paljud haigused väidetakse olevat saadud metsast, veest, tulest jne, mis tähendab, et haigestunud on ühel või teisel moel solvanud vastavaid haldjaid. Ülimalt tõsiselt tuli suhtuda ka surnutesse. Kalmistul sobimatut käitumist või surnute suhtes ilmutatud lugupidamatust karistasid roditelad, kelle all tuleb mõista esivanemaid või suguvõsa surnuid üldisemalt. Muidugi pidi arvestama igasuguseid käitumisnorme, mis sageli olid seoses ka inimese ealiste ja sooliste iseärasustega. Eriliselt oli tähelepanu all raseda (kohtunke, vacanke) naise käitumine, kelle eksimuste pärast pidi kannatama laps.

Vähemalt sama tugev kui haldjausk, on vepslaste nõidususk. Sageli peetakse haigust teise inimese põhjustatuks, olgu siis (pool)tahtmatult kaetades või lausa pahatahtliku nõiduse kaudu. Lastehaiguste põhjuseks öeldakse enamasti kaetamine. Ühelt poolt on väikelaps väga tundlik, teiselt poolt aga oleks meelevastane eeldada, nagu oleks pisikesel isiklikke vaenlasi, kes tema vastu sihilikult kurja sepitsevad. Usutakse, et mõnel inimesel on loomupäraselt hond huba süum (kuri silm), ja see võib mõjuda ilma kurja taotlematagi, iseenesest. Kui mind on kümneid kordi saadetud tarest välja, tehes minu suunas ristimärke ja pomisedes Gospodi pomilui, siis pole see olnud ainult õnnistussoov, vaid pigem püüd annulleerida minust kui võõrast inimesest lähtuvat võimalikku kaetust. Usus kurja silma kahjulikku toimesse pole vepslased mingil moel erandlikud. Nende uskumustes on küll säilinud vanapäraseid elemente, mis mujal on taandunud, aga universaalne hirm kurja silma ees on uskumatult visa teistelgi rahvastel. Leedu materjali kasutades võis Monika Balikiene oma doktoritöös (2012) ümber lükata arvamuse, nagu oleks usk kaetamisse vanemate külaelanike pärisosa. 
Täiskasvanute puhul ei piirduta enamasti arvamusega, et keegi on lihtsalt peale vaadates põhjustanud haigestumise.Tõenäolisem oli kahtlustada pahatahtliku inimese sihipärast nõidust. Ikka võis olla kellegagi äsja olnud äge tüli või siis mõne teisega kauane omavahelisest konkurentsist ja kadedusest lähtuv vastastikune vimm. Nende hulgast tuligi otsida nõidujat. Kõige halvem, mida nõidus võis korda saata, oli pikaajaline parandamatu haigus, mis muutis inimese abituks lamajaks. Meenutades jutustamise ajaks juba surnud nõidu, on mitmel korral mainitud, et see või teine neist pani čogha (pani nurka) oma vihavaenlase, kes võis muide ka ise olla nõid.

\section{Diagnoosimine}

Tänapäeva akadeemilises meditsiinis loetakse endastmõistetavaks, et ravile eelneb diagnoosimine. Teisiti pole see ka vepsa rahvameditsiinis. Silmapaistvaks erinevuseks on see, et paljudel puhkudel diagnoosib haige ise oma häda olemuse ja päritolu. Sealjuures on kõnekad paljud haigusnimetused. Näiteks on üsna tavalise haiguse nimetuseks vepsa keeles koiranniža (koeranisa), mille eestikeelseks vasteks on 'odraiva'. Sel puhul on koeraga seotud nii etioloogia kui ka ravivõtted. Huvitava seigana võib mainida, et ka odratera pole vepslastel selle häiriva haiguse ravis tundmatu olnud (Rainio 1973: 293), kuigi see polnud just kõige tavalisem ravivahend. Haiguse tekkepõhjuseks peeti koera narrimist - näiteks ulatati tema poole toidupala ja tõmmati siis koera eest tagasi või õrritati teda muul moel. Konkreetset juhtumit polnudki vaja meelde tuletama hakata, sümptomid ütlesid kõik ära.

Metsas valesti käitumist võis metshaldjas karistada mecanenanimelise (ka mecakibu - metsahaigus) tõvega, kuid ebamäärasemate tunnuste tõttu polnud see nii hõlpsalt diagnoositav. Heal juhul võis inimesele siiski meenuda vandumine või tarbetu karjumine või ka metshaldjate meenutamine hiljutise metsaskäigu ajal, siis oli asi selge.

Samuti võis unetu, isutu ja pidevalt nutva väikelapse ema (uuemal ajal sagedamini vanaema) ise järeldada, et laps on kaetatud, ning isegi süüdlase kindlaks määrata, meenutades, kes last olid enne tema haigestumist vaadanud. Põhjus, miks uuemal ajal diagnoosivad lapselapse kaetamise pigem vanaemad ja lähevad temaga ravimiseks tedai juurde, peitub lihtsas tõsiasjas, et vepsa külades sünnib lapsi ülivähe ja haigestunud lapsed on enamasti suvekülalised. Asi pole selles, nagu ei usuks tänapäevased vepsa päritolu noored emad ise kurja silma. 
Kui aga haige ise ei oska enda või lapse häda põhjust leida, on vaja pöörduda spetsialisti poole. See, kes muiste sageli otsustas, millest haigus on tekkinud, oli nõid. Kui arst püüab mitmesuguste vaatluste ja proovidega anda diagnoosi, siis nõid arbus (arboi) haiguse põhjustaja kindlakstegemiseks. Seejärel võis ta anda ettekirjutuse ravi suhtes. Nagu juba öeldud, on tänapäevani haiguse põhjuseks sageli peetud nõidumist ja seda on eriliselt kardetud. Ühe mullegi tuttava Järvedes elanud naise T. O. surmajärgsel suvel kõneldi mulle, et teda olid pikemat aega vaevanud sisemised valud, ta polevat midagi süüa saanud, vaid kõik välja oksendanud. Naabrite ja hõimlaste jutu järgi polevat ta haiglasse arsti juurde läinud, küll aga lasknud arbuda kahel arbujal (üks neist vepslane, teine mustlane). Mõlemad olid andnud rahustava vastuse, et ta pole ära nõiutud. Järelikult oli haige esmane hirm ja iseenese pandud diagnoos nimelt nõidus. Kui see hirm põhjendamatuks osutus, kannatas ta füüsilisi vaevusi enam kellegi poole pöördumata surmani. Samas avaldasid inimesed, kes T. O. lugu rääkisid, ka külas ringelnud, samuti ilma uuringute ja arstita pandud, kuid akadeemilise meditsiini haiguste liigitusse kuuluva diagnoosi: arvati, et tal oli maovähk.

Ka siis, kui teadja oli kindlaks teinud, et haiguse põhjuseks on nõidus, oli tulemusrikkaks raviks vaja teada, kes oli nõiduja. Võis juhtuda, et esialgne kahtlus langes valele inimesele, nii et ka esialgne ravi polnud piisavalt tõhus. Sel juhul tuli uuesti arbuda, kuni paljastus tõeline pahategija. Nii näiteks pidas teadja Vidlas elava V. L. haigestumises alguses süüdlaseks tema ämma, kuid teistkordne arbumine osutas, et nõiduja oli hoopis lähikonnas elav mees.

Teadja, nõid või diagnoosi kontekstis kõigepealt arbuja (vepsa arboi) kasutas mitmesuguseid abivahendeid, nagu karvapallist pendel, kivikesed, vesi, söed, ka mängukaardid jm.

Kui häda oli tekkinud nõidusest, oli selle kõrvaldamiseks vaja vastunõidust. Üldjuhul jäi see sama teadja hooleks, kelle poole oli pöördutud, kuid vahel soovitas see ka kedagi teist, keda pidas endast võimekamaks. Kui tegemist oli normirikkumisest johtuva tõvega, võis ravi jääda ka haige enese asjaks. 


\section{Raviviisid ja ravijad}

Vepsa rahvameditsiini põhilised parandamisvõtted on akadeemilise meditsiini seisukohalt vaadatuna ilmekalt maagilise alusega, mis haiguste etioloogiat arvestades ongi ootuspärane. Uurijate poolt ratsionaalsetena esile tõstetud ravivõtetel on pigem marginaalne osa. Samas on mu enda pika aja vältel toimunud välitööd, mille käigus on aset leidnud palju jutuajamisi haiguste ja tervendamise teemadel, osutanud, et mu vestluskaaslased ei tõmmanud sel viisil piiri. Võiks öelda, et piiri lihtsalt ei tajuta - ja siis pole ka mingit vajadust siduda üht või teist poolt mingite hinnangutega. Ingerisoome materjali uurinud Taisto-Kalevi Raudalainen on esitanud rohkesti parandamislugusid, milles kirjeldatud ravimeetodid oleksid kaksikjaotuse maagilineratsionaalne kohaselt pikemata maagia poolel, kuid jutustajad ei tee sellest probleemi, st ei püüa midagi maha vaikida ega distantseeruda (Raudalainen 2008). Võidakse hoopis vastandada rahvaravitseja häid tulemusi arstide võimetusele (samas: 182, 194) ja väärtustada usku inimestesse kõrgemalt kui usku arstidesse (samas: 176).

Pärimusühiskonnale pole vastuvõetav seisukoht, nagu põhineksid rahvameditsiini raviviisid pelgalt usul. Usk muidugi on, kuid see põhineb kogemustel. Ja kogemustele tuginemine omakorda peaks olema ratsionaalne. Mõistlik inimene pöördubki ju selle poole, kellelt on varem abi saanud naabrinaine, nadu ja täditütar. Uue ja tundmatu, kogemuse poolt kontrollimata abistaja otsimine on selgelt ebamõistlik. Oluline on terveks saada, sündigu see sõnade või taimetõmmise abil.

Eks ole just kogemused, nii teiste kui enda omad, need, mis annavad põhjust väita, et rästikuhammustuse korral on kõige tõhusam sõnadega ravimine. Eks ole ju oma väikeste laste ja hiljem lastelastega, kes lakkamatult nutsid, käidud teadja juures ja väikesed ongi paranenud! Kogemus on see, mis kinnitab sõnade ravivõimet täpselt niisamuti nagu on kogetud, et katkihõõrdunud kannale või varbale mõjub hästi teelehe pealepanemine. Seda võis teha igaüks kas iseendale või oma lapsele, sellepärast polnud veel vaja minna teadja/nõia juurde. Juha Pentikäinen on Karjala materjali põhjal näidanud, kuidas jagunesid ravivõtted mitmeks kategooriaks, millest esimene oli igas peres tuntud ja praktiseeritav, aga viimased ainult spetsialistide hallatavad, sealjuures mõnda võtet teadsid ainult vähesed (Pentikäinen 1971).

Küllalt sageli oligi haige ise enda arstija. Peale üldtuntud taimede võidi näiteks haavu, nahahaigusi, valutavaid kohti määrida toiduõliga 


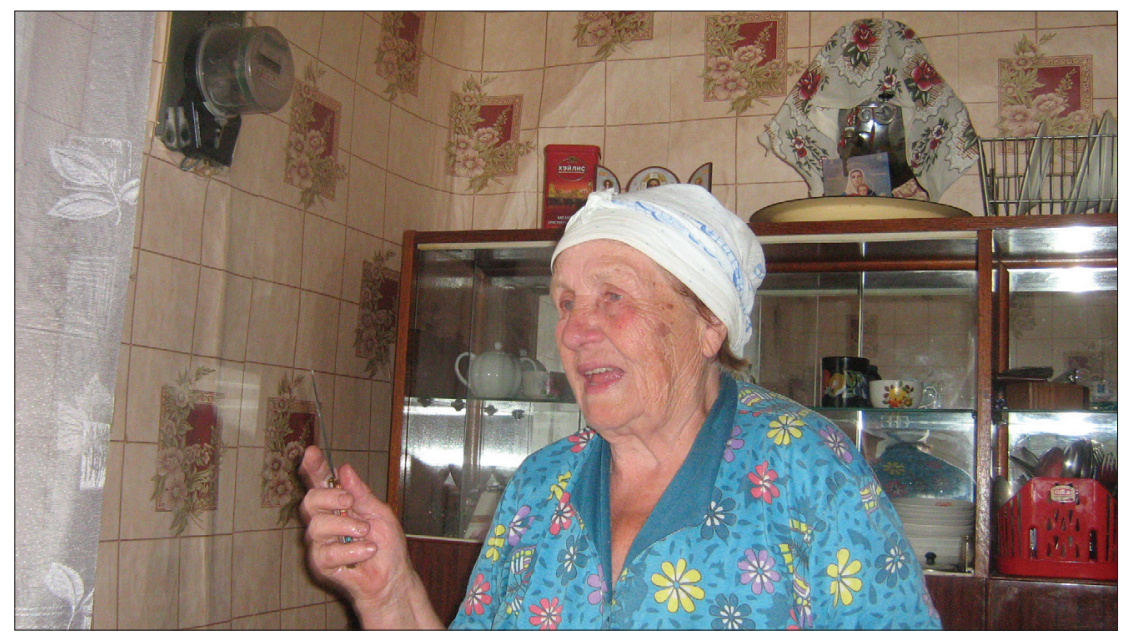

Foto 2. Üks tänapäeval Vidlas tegutsevatest ravitsejatest. Eva Saare foto 2010.

(pühasine voi 'paastuvõi/õli'). Õli kindlasti on pehmendava toimega ja ammune ravim, mille kasutamise kohta leidub näiteid Piibliski. Sellest lähtus õli kasutamine õigeusu kiriklikus praktikas ning see andis õlile teatud pühaduse. Samuti oli kindel ja esimeses järjekorras kasutatav ravivahend riśtvezi, millest järgnevalt lähemalt.

Kui oli selge, et häda on tekkinud enda süül, tuli see ise ka parandada. Seda tehti prostmas (andeks palumas) käies vastavalt tekkekohale - metsas, veekogu ääres, kalmistul, saunas jne. Andekspaluja kummardas kolm korda ja palus "Prostkat mindai gŕähkišt, hubin radoin" (Andke mulle patusele andeks, tegin halvasti) või pisut teiste sõnadega, st vabas vormis. Kummardused, mis on laialdaselt kasutusel õigeusu kombestikus, näitavad paluja alandlikkust, enda andmist palutavate meelevalda. See on usu asend, mida tugevdab veel ristimärgi tegemine. Seda on väga lihtsalt põhjendatud: "Ved ii jüged riśttä süumad $i$ sanuda: Gospodi pomilui!” (pole ju raske risti ette lüüa ja öelda: Issand, heida armu!). Ristimärgi tegemises pole nähtud vastuolu sellega, et andekspalumine võis olla suunatud metsa- või veehaldjale, seda enam, et juba palves võis paigahaldjatele lisaks olla nimetatud ka sü̈nduižem śötai (kallis Jumal). 


\section{Taimravi ja teised "ratsionaalsed" ravivõtted}

Üldiselt ratsionaalseteks peetavate ravivõtete kõige tuntuma osa moodustab taimravi. Tuleb tunnistada, et see on vepslastel üsna tagasihoidlikul järjel. Neistki suhteliselt vähestest ravimtaimedest, mida tänapäeval teatakse, on mitmed võõrliigid. Sageli väidetakse, et nende kasulikkusest on loetud või kuuldud raadiost.

Üks põhjusi on kindlasti tõsiasi, et juba taimede tundmine on tänapäeva metsarahvast vepslastel paradoksaalselt kehv. Hoopis omaette teema on, et tuttavategi taimede kohta kasutatakse viimastel aastakümnetel väga sageli vene keelest laenatud nimesid: seda on muide üldise seaduspärasusena esinenud keelevahetuse staadiumis olevatel rahvastel ja rahvusrühmadel, ka näiteks eesti siirdlastel. Nii on tänapäeval tuntud ja kasutatavate taimede hulgas kalin (lodjapuu), mat' i mačeha (paiseleht) jne.

Muidugi on ilma meditsiinihariduseta inimene mõnelgi puhul ravimtaimedena nimetatute mõju suhtes nõutu: tõepoolest, köha vastu võib tõesti abi olla, kui keeta jõhvikaid, panna suhkrut hulka ja juua. Aga kas siin on oluline jõhvikas? Kas pohlad poleks sama head? Või kolmandad-neljandad marjad? Või põhineb toime eeskätt joogi kuumusel?

Ravimiseks kasutatud taimede seas leidub selliseid, mille nimes antakse juba haiguse nimetus, mille puhul neid kasutada. Mõned nende hulgast võivad käibearusaama taimravist kui ratsionaalsest pea peale pöörata. Üheks väga tavaliseks haigusseletuseks 21. sajandini välja on olnud kaetamine - prizor, mis oli mitmel moel ilmnevate hädade põhjus ja ka üldnimetus. Nii oli ka prizorkibu - kaetushaigus või -valu. Kui selle vastu arvati olevat abiks prizorhiin (kaetusrohi), siis taime kasutamisel tee või tõmmisena võiks veel tekkida kujutelm ratsionaalsest taimravist, hoolimata usundilisest etioloogiast.Tegelik kasutusviis lükkab niisuguse oletuse ümber: kaetusrohi nimelt kuivatati ja siis suitsutati sellega kaetatut. Kuna kaetus oli üks tavalisi haigusseletusi, leidus ka erinevaid raviviise. Võib päris loomulikuks pidada, et kõige tõhusama mainega oli sõnadega arstimine. Muide, ka Eesti rahvameditsiini ravimtaimede andmebaasis HERBA on ära toodud kaetuse jm sarnaste hädade vastu tarvitatud taimed, ning seda lahendust võib ainult heaks pidada. Koostajad pole võtnud endale (ja kellele tahes teisele) üle jõu käivat ülesannet eraldada ratsionaalsed ja maagilised haigusseletused, -nimetused ja ravivõtted, kaasates andmebaasi ainult esimesteks arvatud (Sõukand \& Kalle). 
Prizorhiin pole ainuke ravimtaim, mille nimi viitab haigusele. Vepsa haigusnimi purend on seotud verbiga purda (pureda) ja sellega tähistatakse ühelt poolt (luu)valu, teiselt poolt aga hoopis ebamäärasemaid vaevusi, eriti väikelapsi tabavaid, kes ju ise ei oska ennast tabanud valude täpsemast asukohast ja loomusest teada anda. Seda haigust raviti taimega, mille nimi oli vastavalt tõvele purendhiin ja mis pidi olema kivisel maal kasvav väikeste kollaste õitega taim.

Samas ei olnud see taim ainus, mida laste purend-tõvest ravimiseks kasutati. Selle kõrval olid tuntud arstirohuks ka kägenmarjad (käomarjad) - näsiniine marjad. Kas oleks sel puhul tegu ratsionaalse ravivõttega? Populaarsest botaanikast on meelde jäänud, et näsiniin on mürgine. Selliseid haigusnimetusele vastavaid ravimtaimede nimetusi on terve rida (Semakova \& Rogozina 2006: 303). Aga kuitahes palju ka oleks fikseeritud ja fikseerimata ravimiseks kasutatud taimi, on ilmselge, et ainult nende peale ei loodetud. Ka siin nimetatud purenda vastu kasutati võib-olla sagedaminigi läbiproovitud, kogemuste põhjal toimivat sõnadega ravimist.

Taimravi marginaalsuse juures on mõtet meenutada veel ühte ainult esmapilgul - paradoksaalset asjaolu: väheste nimetatud ravimtaimede hulgas on viimastel aegadel üsna olulisel kohal võõrliigid, nagu näiteks must aroonia ja tšillipipar. Viimast võib väga sageli näha kasvamas vepsa tarede aknalaudadel potis. Teadmised nende taimede tervistavast mõjust on sageli väidetavasti pärit raamatust või ajalehest, kuigi ega sellekohaseid ütlusi igakord uskuda tasu. Viitega kirjasõnale tahetakse ehk ainult tõsta nende autoriteeti, tegelikult võib olla jutustajale seda taime soovitanud tema naabrinaine, sellele omakorda näiteks Vidlas elav lang, aga see poleks nii austustäratav. Kuna kirjasõna on vepsa rahvakultuuri mõjutanud õige vähe, on selle autoriteetki suur, aga samas irratsionaalne. Sarnast "raamatuusku" on muidugi laiemaltki esinenud, muuhulgas näiteks Eestis, kus ju ometi on üsna vana üldine kirjaoskus.

Ravimtaimed on rahvusvaheliseltki pälvinud rohkem uurijate tähelepanu, sest nagu öeldud, nähakse just neis sisalduvat rahvameditsiini kvintessentsi. Vepsa andmestik osutab, et taimede kõrval kasutati rahvameditsiini n-ö ratsionaalse poole peal üsna laias ulatuses mitmesuguseid loomseid ja elutust loodusest pärinevaid substantse. Heidame pilgu neilegi, vaadeldes ühtlasi nende raviainete seoseid haiguste nimetuste ja etioloogiaga. Vaatamata seisukohale, et maagilise ja ratsionaalse vastandamine pole vepsa rahvameditsiini käsitlemisel ülepea relevantne, on ühel või teisel konkreetsel juhul sellel eraldi peatutud. 


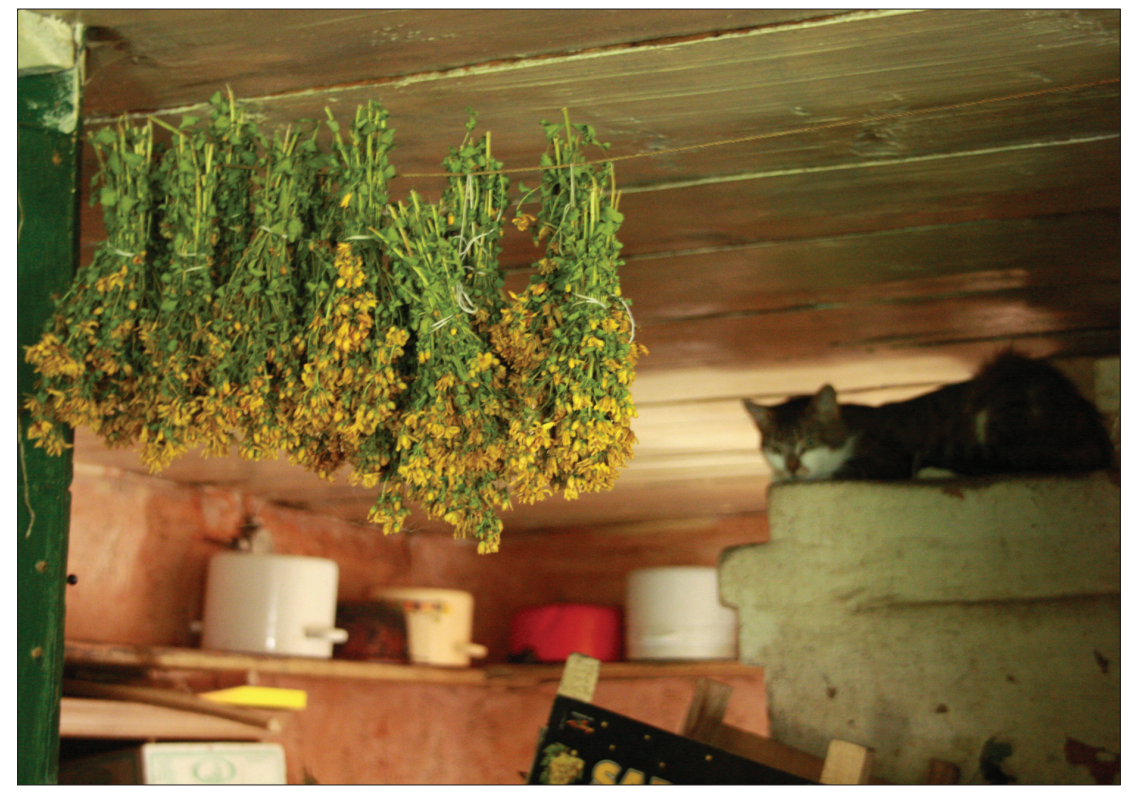

Foto 3. Kuivavad ravimtaimed vepsa pertis. Päžar.

Madis Arukase foto 2015.

Eespool oli juttu koiranniza-nimelisest haigusest, mis, nagu ka koiranvaivuz, on nime saanud selle järgi, et et haiguse põhjustaja on koer või õigemini inimese normivastane käitumine koera suhtes. Loomanimest tuletatud haigusnimed pole aga alati seotud etioloogiaga, sageli on nad pelgalt kujundlikud. Vepsa keeles kannab spetsiifiline nägemispuue nimetust kukoińsüumad (kanapimedus, sõnasõnalt 'kukesilmad'). Selle parandamiseks kasutati kas jänese või lutsu maksa. Maks oli vepslastel (nagu ka eestlastel) tunnete keskus ja eriliselt tähtis (vepsa maks, makseine on tänini tuntud tähenduses 'kallim, armastatu'), tänapäeva eesti keeles võib kohata selle asemel saksamõjulist 'südamekest'. Zaitseva ja Mullonen on selle tähenduse esitanud homonüümina (Zaitseva \& Mullonen 1972: 319), nägemata semantilist seost. Miks just jänes ja luts? Irina Vinokurova monograafiast ilmneb, et et jänes on kandnud märkimisväärselt palju vastandlikke usundilisi tähendusi (Vinokurova 2006: 138-145). Luts (madeh) selliseid tähendusi ilmselt ei evinud 
(samas: 214-215), kuid ehk mängis siin mingit osa lutsu öine eluviis. Võimalik põhjus võib olla seegi, et algriimi soosivas vepsa keeles kõlab madehen maks palju paremini kui haugin maks, kuigi haugile omistati vägagi palju usundilisi tähendusi. Haugi hambad kaitsesid haiguste eest, aga neid kasutati ka ravimisel (samas: 209-213).

Üks veel minu kogumismatkade ajal laialt tuntud loomne ravivahend oli murazvoi (sipelgavõi, ehk pigem sipelgaõli). Sellega raviti haigeid jalgu ning seda valmistati pudelisse meelitatud sipelgatest neid ahjus kuumutades.

Samatoimelist ravimit saadi ka koos sipelgatega kotis koju toodud sipelgapesa kuuma veega hautamisel.

Ei oska arvata, kuidas võis uuemal ajal levida kölnivee (dikalon) kasutamine. Igatahes on mõnedki mulle kinnitanud, et määrivad sellega haigeid kohti, peamiselt põlvi, küünarnukke jt liigeseid.

Mineraalsetest vahenditest võiks mainida Viĺhala külastu lähistel paiknevatest savimaardlatest saadavat hallikat savi, mis oli hinnatud maavara ka selle tõttu, et seda kasutati ahjude valgendamiseks. Väidetavasti oli selle sinakashalli savi mähiste abil saadud leevendust liigesehaiguste puhul ja isegi operatsioonihaavade paranemine kulgevat kiiremini ja komplikatsioonideta, nagu samas külastus kõneldi. Saviga ravimist teati ka Šondjalas.

Sool on rahvusvaheliseltki olnud teada-tuntud maagiline vahend. Muuseas tarvitasid vepslased seda metshaldja käest kadunud inimese või looma väljanõudmisel. Haiguste raviks on erinevatel puhkudel kasutatud soola, millele olid sõnad peale loetud. Soola kui keemilise aine iseeneslikku tervistavat mõju ilmselt ei eeldatud.

Raud on inimorganismile vajalik aine, mille vaegust on tänapäeval ametlikus meditsiinis mõnel puhul vastavate tablettidega leevendada püütud. Kui aga vepslased on pidanud heaks anda sünnitajale rauaräbu (Kettunen 1943: 43), siis on selle taga ilmselge analoogiamaagia patsient peaks arstimise tagajärjel saama tugevaks kui raud.

Manuaalteraapiat võiks pidada küll ratsionaalseks, kuid ometi on sellelgi tugev uskumuslik taust. Näiteks juba mitmesuguste massaaživõtete kasutamisel lihaste ja soonte hädade puhul oli sooritatavate liigutuste tugevuse, suuna jms kõrval väga oluline teadmine ravitseja võimekusest. Üldjuhul omistati "head käed" ka puhtmaagiliste vahendite kasutamisega mainet kogunud inimesele. Teiseks näiteks võib tuua juba mainitud naba paikapanemise, mis põhineb väga erinevate sisemiste hädade seletamisel paigast läinud nabaga. 


\section{Vesi}

Vett kasutatakse paljude hädade vastu nii sees- kui ka välispidiselt. Samas on raske leida näidet, kus vett iseenesest oleks peetud parandavaks. Kui haiget veega pesti või üle kallati, siis oli tegemist erilise veega ja sellega kaasnesid toimingud, mis aitasid vee puhastaval toimel mõjule pääseda. Vahel võiski vesi olla ainult vahendaja, mis kandis sõnade või pühade esemetega kokkupuutumisest saadud väge.

Siinkohal on aeg võtta kõne alla pühitsetud vesi, riśtvezi (ristivesi). Pärast kirikute sulgemist 1930. aastail on vee pühitsemist toimetanud ilmikud. See on toimunud risti vettekastmise või ikoonide pesemise näol, nagu olen seda näinud palju kordi erinevate külade pühadel.

Ristivett on kõigepealt kasutatud kohapeal pärast vee pühitsemist enda haige koha kastmiseks. Tavalisim on liigesehaiguste sagedusest johtuvalt jalgupidi vette minemine ja vee tõstmine peopesaga säärtele, põlvedele, ka käeliigesed saavad kastetud. Tihti uhutakse pühitsetud veega ka nägu. Tänapäevaks näib põhjalikum suplus küll taandunud olevat, aga üksikjuhtudel on mindud üleni vette veel lähiminevikus.

Pühadelt koju minnes võetakse ristivett koju kaasa. Heatahtlikud võivad seda viia ka ise pühal mitteosalenud eakatele ja haigetele naabritele, nagu on selgunud ümbritsevatele suunatud märkustest a la: Ven Sašu-svatule möst, hän läžub (Viin Saša-langule ka, ta on haige). Päris tavaline on ristiveega pudeli hoidmine ikooninurgas (jumoukod, jumoučok). Haigestumiste või lihtsalt halva enesetunde puhul on seda rüübatud.

Ühenduses pühitsetud vees suplemisega külapühade ajal tuleb meenutada üht vepsa usundilise traditsiooni tähtsat elementi - tõotamist. Enda, oma pereliikmete või kodulooma, eeskätt lehma kui tähtsa elatusandja haigestumise korral on antud tõotus paranemise korral minna sellele või teisele pühale ja supelda. Kasutusel oli omasõna toivotta (tõotada), kuid ka venelaenuline zavetoita või panda zavet. Tihtipeale sellest ka piisas - haigus paranes. On teateid ka sellest, et arbumise teel määrati, millisele pühale peaks minema. Üldiselt on minu tähelepanekute järgi oldud hoolsad ka lubatut täitma. Mõnel puhul on see siiski objektiivselt võimatu olnud, näiteks kui tõotuse andja (see võidi anda lähedase inimese või koguni lehma paranemise nimel) on lubatud püha ajaks ise haigestunud. Sel juhul on püütud minna mõne teise küla ajaliselt hilisemale pühale, et tõotus oleks põhimõtteliselt, kuigi mitte täpselt, täidetud. 
Vahel muutis vee väeliseks see, et ta pärines näiteks kolmest voolavast veekogust - jõest, ojast, allikast, et võtmiskoht oli määratletud ja vett võttes oli palutud veehaldjaid: Ižandaižed, emägaized, andkat vedut ii hitrostin täht, a necen raba božijan spravitada (Isandad, emandad, andke veekest, mitte kavaluse jaoks, vaid selle Jumalasulase (või -ümmardaja) arstimiseks). Pärast vee võtmist tänati haldjaid.

Vett, millele olid sõnad peale loetud, kasutati pesemiseks, aga seda anti ka haigele juua. Pesemised või ülevalamised kuulusid üldiselt teadjate kompetentsi. Protseduure viidi läbi saunas või tares tala (matic) all.

\section{Sõnad}

Rahvausundipõhiste raviviiside hulgast on olnud ja on 21. sajandi algul jätkuvalt kasutusel maagilised toimingud ehk taiad ja maagilised tekstid ehk loitsud, enamasti kombineeritult.

Nii rahvaarstid kui nende patsiendid on olnud ühtmoodi kindlad selles, et just sõnad on kõige tähtsamad. Paljudel kordadel, kui vestluskaaslane on kõnelnud näiteks arstimisest saunas vihtlemisega, veega ülevalamisega või muul viisil, on puändina kõlanud see kinnitus.

Juba tõsiasi, et terminid on omakeelsed, osutab genuiinsusele. Kõige tavalisem loitsu tähendav vepsa termin oli lihtsalt vaihed (sõnad). Vepsa vajeh tähendabki lihtsalt 'sõna' kõige argisemas mõttes, terminina kasutatakse mitmuslikku vormi. Mingit noid-esikomponendiga liitsõna või sõnaühendit pole vepsa keeles ilmselt olemas. Teine üldisem nimetus on puheg, mille etümoloogia pole nii läbipaistev, kuigi seoseid võib leida nii kõnelemist kui ka puhumist tähendava verbiga puhuda. Puhumine võiski olla osa arstimisriitusest, isegi ainus või oluline, nagu Jussi Rainio toodud näites, kus pudelisse puhumine parandas paistes ja valutava rinna (Rainio 1973). Puhudes väljuv hingeõhk oli ju elujõu kandja ja lapse haige koha peale puhumine on selle uskumuse rudiment.

Mis puutub läänemeresoomelisse verbi loitsida, siis eesti keeles on sel sõnal nõrk murdetaust ja neiski üksikutes kihelkondades, kus see esineb, on ta tähendus kõikuv. Eesti kirjakeele loits on soome laen. Võib täheldada, et vana ühise tüve semantiline areng on kulgenud erinevates keeltes erinevaid teid pidi.

Vepsa keeles on küll olemas rahvapärane verb loita, kuid see on omandanud kristliku tähenduse loiciba pagastas (palvetasid kirikus), 
selle kõrval on näiteks ka sõimamist või kirumist märkiv tähendus (Zaitseva \& Mullonen 1972). Mõlema semantiline ühisosa osutab erilisele, tavapärasest põikuvale keelekasutusele.

Teine vepsakeelne aktiivses kasutuses olev loitsutermin puheg on seotud verbiga puhuda, mil nende paljude tähenduste kõrval, mis esinevad ka eesti keeles, on ka (ehk arhaismina) inimese artikuleeritud kõnet (vrd soome puhua) märkiv tähendus - pühä jumou śötai, abuta puhuda puhegid (püha Jumal-toitja, aita sõnada sõnumisi). Muidugi on toodu vaid üks võimalus tõlkida väljendit puhuda puhegid; muudeks on näiteks 'lausuda lausumisi' või ka 'loitsida loitsimisi'. Puhuda-verbiga ja sõnaühendiga puhuda puhegid võib aga olla silmas peetud ka puhumist eestikeelses tavatähenduses: haige koha (või arstimi) peale võidi tõepoolest puhuda, mille kohta on andmeid nii vepslastelt kui ka kasvõi tänasest üldtuttavast eesti kodusest lastemeditsiinist. Kaasneb ju arstimissõnade lausumisega muidki tegevusi: artikuleerimata häälitsusi, sülitamist, piiramist, ristimärgi (märkide) tegemist jne.

Selge on igatahes, et tänapäeva vepsa keeles ei kasutata puhudaverbi kõnelemise tähenduses, ja igal üksikjuhul ei selgugi, kas on mõeldud puhumist või sõnade lugemist. Võtame näiteks teate, kus juttu kõrvavalu arstimisest sel teel, et eidekesed 'puhuvad' kõrva ( $p u$ hutaze akeižed korvha - Rainio 1973: 297). Ühelt poolt võidi pominal kõnelemisel tekkivat õhuliikumist tajuda kerge puhumisena, teiselt poolt võis parandaja ka tõepoolest puhuda, kuigi tõenäoliselt kaasnes sellega sõnaline komponent.

Igatahes on huvitav, et ka komi keeles on maagiliste ravivõtete kohta kasutusel sõna, mille tõlkevaste on puhuma, ära puhuma (Iljina 2008: 82).

Need vaihed ja puheged olid pühad ja toimekad sõnad. Sellepärast oli oluline nende õigsus, kanoonilisus.

2006. aasta suvel naeris tuntud Vidla teadja T. J. täiest südamest, meenutades nõiasõnu, mida talle keegi oli raamatust ette lugenud (kõne alla tuleb ehk M. Zaitseva ja M. Mulloneni raamat kui Venemaal kahtlemata kättesaadavaim, kuid täiesti välistatud pole ju ka Soomes avaldatud tekstikogumikud). Need olid T. J. meelest naeruväärsed, sest nad polnud õiged, st nad ei kattunud talle teadaolevate sõnadega, nad ainult püüdsid näida arstimissõnadena. See tähendab ühtlasi, et neil polnud mõju, nendega arstimine oleks olnud kasutu, haigus poleks nendele sõnadele alistunud. Ideaalis peaksid kõik samal otstarbel ühes keeles kasutatavad loitsud olema identsed. Nii see muidugi pole 


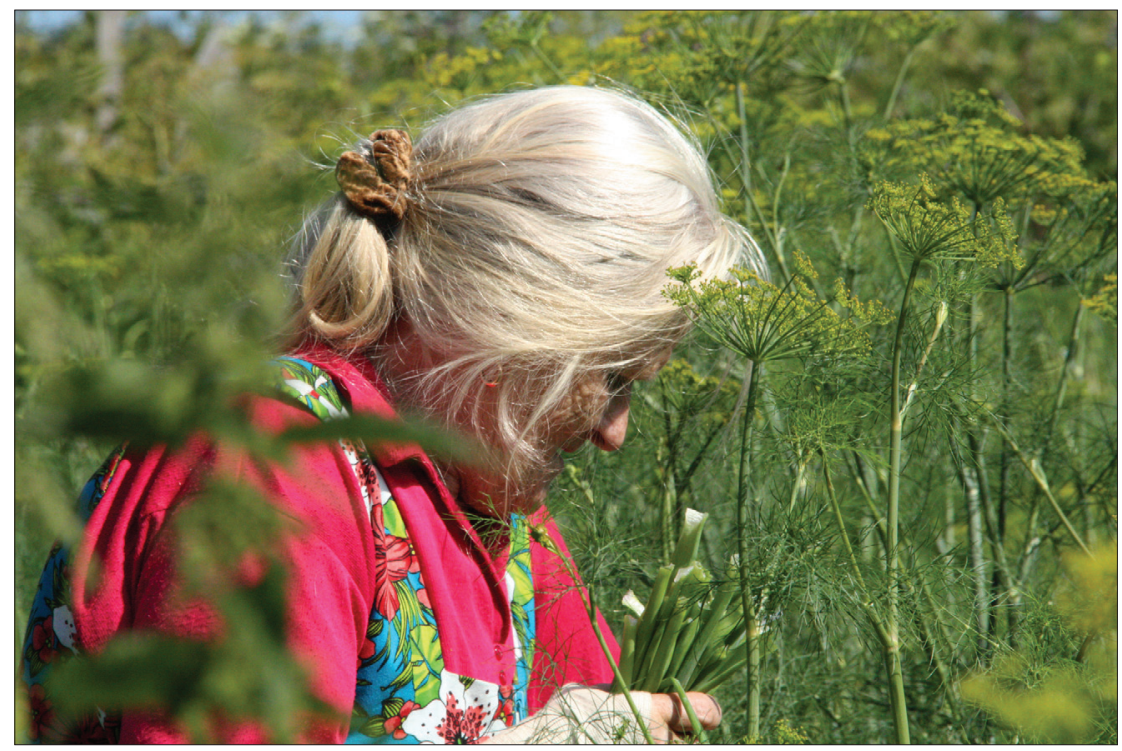

Foto 4. Tuntud Vidlas elanud teadja, kelle põhiliseks töövahendiks oli sõnamaagia. Madis Arukase foto 2009.

ega saagi olla. Isegi kõige suurema hoolega meeles peetu kaldub muutuma: mälu veab alt, nagu arvatavasti igaüks on kogenud erinevate tekstide puhul. Loitsudel tekivad variatsioonid nagu iga teise suulise pärimusliigi puhul.

Samas, teades uskumust, et sõnade edasiandmisel nende toime kaob, kerkib mõttesse küsimus, kas ja kui “õiged” on ülepea talletatud (ja trükis avaldatud) loitsud. Ehk on kogujale esitamisel meelega midagi ära jäetud või muudetud? Et sellist asja võib oletada, tunnistab ka Mägäŕves kuuldud jutustus mehest, kellele justkui olid edasi antud sõnad, millega metshaldjaid välja kutsuda. Et teadja oli aga ühe sõna ära jätnud, pääses heas usus metsa läinu vaevu eluga. Enda kogumistööle mõeldes on raske mõista, miks mõned teadjad on nii- või teistsuguse põhjendusega loitsude esitamisest keeldunud, teised aga ilma märgatavate siseheitlusteta soostunud neid mikrofoni lugema. Võibolla lähtusid viimased - või osa neist - just n-ö moonutamistaktikast?

Uue aja märgina olen näinud ka kasutajate endi kirjapandud nõiasõnu, need on olnud omaloodud ortograafias ja kirillitsas. Olen 
isegi kopeerinud neid, tõsi küll ümber kirjutades, kuna pole olnud võimalust kasutada koopiamasinat. 20. sajandi lõpupooles olid vepslased tasapisi hakanud olulisi tekste ise kirja panema ja loitsud polnud sealjuures ainsad. Olen näinud ka kirjapandud kristlikke palveid, ja Marje Joalaid kirjeldab itkemist käsikirja järgi (Joalaid 2000). Kui see näib tõepoolest olevat vastuolus žanrispetsiifikaga, siis loitsude kirjapanemine on näiteks Eestis olnud vägagi tavaline alates 19. sajandist (Kõiva 2011a, 2011b).

Millised on siis vepsa nõidussõnad? Valdavalt on need funktsiooni poolest arstimissõnad, kuid leidub muidki, näiteks haldjate poole suunatud pöördumisi (nn palveloitse) majandusõnne taotlemiseks või julgeoleku ja heaolu tagamiseks metsas ööbimisel, uude majja kolimisel, saunas käimisel, marjule minekul, uue looma lautaviimisel jne.

Olemuslikult võibki eristada palveid, palveloitse, soove ja manamisi. Palvete alla võib liigitada ka ravimisprotseduurides väga sageli tarvitatud andekspalumised, mis üldjuhul koosnevad pöördumisest üleloomulike olendite poole ja lõpevad lakoonilise, tihti ühesõnalise palvega prostkat (andke andeks).

Struktuurilt võib veel eristada lühikesi vormeleid, jutustavaid ja dialoogloitse. Üldiselt on uurijaile pakkunud huvi pikemad süžeelised loitsud, kuid väga paljude hädade ravimisel kasutati tegelikult just lühivormeleid. Tihti kaasnesid sellised vormelid maagilise tegevusega. Näiteks nimetatud koiranniža puhul, mille üks levinud raviviise oli sooja piruka või leivaga vajutamine ja siis (vasakule) heitmine, mille juurde käiv vormel võis olla (oli ka teisi) selline: Koir, na, ota ičeiž niža (Koer, säh, võta oma nisa). Asja mõte oli selles, et koer sööb enda kaudu tekkinud haigusega kontaktis olnud leiva ära ja haige vabaneb hädast. Samas oli ikkagi oluline nimetada nii koera (haiguse põhjust), tema nisa(haigust) kui ka soovi.

Toodud näites lõpetas sõnaline vormel arstimistoimingu, teistel juhtudel on sõnad saatnud maagilist tegevust. Eespool oli jutuks purend-nimelise haiguse taimravist ja selle küsitavast ratsionaalsusest. Tuntud oli ka maagiline ravimine sõna ja teoga. Dialoogloitsu saatel näriti või imiteeriti haige koha närimist; kõrvalseisja küsis: "Mida pured?" Närija vastas keskse vormeliga: "Puren purendan" (vrd eesti Närin nari), millele järgnes kõrvalseisja kinnitus: "Pure igaks kaikeks, amin" (Pure igaveseks ajaks. Aamen).

Samalaadne oli ravi lapse puhul, kes kaua käima ei hakanud: dialoogloitsu saatel raiuti läbi teed või jalgu köitvad kujuteldavad sidemed. 
Raiumisega raviti ka seljavalu ja kõrvaldati maagilised tõkked, mis polnud lasknud meheleminekuealisele tütarlapsele kosilasi tulla.

Amin kas üks või kolm korda lausutuna on kinnitus, mis on väga püsivalt kuulunud arstimissõnade lõppu. Seda kristlikku kallakut osutab ka abistatava nimetamine jumalasulaseks (või -ümmardajaks). See tiitel on kasutatusel venelaenulisena, mida käänatakse (nagu juurdunud laene kunagi) vepsa keelele omaselt. Haige niisugune määratlemine koos algus- ja lõpuvormelitega osutavad, et taotletakse jumalikku kaasaaitamist. Olen kuulnud üht vepsa teadjat väitvat, et kui poleks Jumalat, ei saakski sõnadega arstida. Aga saab ju - järelikult Jumal on. Kristliku ja mittekristliku põimumine on vepsa rahvameditsiinile niisama omane kui kogu sünkretistlikule vepsa rahvausundile.

Vepslastel kasutusel olevatest mitut tüüpi lühematest arstimissõnadest võib peale eeltoodute (käskvormelid ja dialoogloitsud) esile tuua veel kut ...muga struktuuriga loitse. Seda tüüpi sõnad on orienteeritud situatsioonide sarnasusele: Kut vahvas seižub nece päč, laske muga vahvašti uindab laps (Kui tugevalt seisab see ahi, las nii tugevalt uinub laps) (Semakova \& Rogožina 2006).

Suuremat huvi on äratanud pikemad, jutustavat laadi historiolaloitsud. On arvatud, et jutustavad loitsud - või vähemalt see struktuuritüüp - on venelaenuline või -mõjuline (Turunen 1952). Temale tugineb ka Pekka Hakamies (1994), tuues tõenduseks informantide kinnitusi samade loitsude oskamisest nii vepsa kui vene keeles jms. Tegelik olukord on ilmselt keerulisem. Ühelt poolt on nii Aimo Turunen kui ka Pekka Hakamies kasutanud peamiselt Äänisvepsa andmeid, kuid see piirkond ongi tugevama vene kallakuga kui teised vepsa murdepiirkonnad: näiteks asendusid seal emakeelsed itkud juba varakult venekeelsetega. Teiselt poolt ei näi loitsutekstid vepsa keeles ilmutavat põhimõttelist piirkondlikku erinevust. Küllap on vepsa ja põhjavene, eriti vepslastega piirnevate alade loitsudel nii mõndagi ühist, kuid midagi konkreetsemat ei saa väita seni, kuni puuduvad korpusväljaanded nii vepsa kui ka vene loitsudest.

Kõige tavalisem - kuid mitte sugugi ainuke - vepsa jutustavate loitsude tüüp kujutab kokkuvõtlikult öeldes loitsija teekonda üleloomuliku abistajani/abistajateni (või abivahendini) ja seejärel haiguse hävitamist. Üldjuhul algab selline loits hommikuse tõusmisega (vahel ka juba magamaheitmisega eelmisel õhtul), pesemise, riietumise ja teeleasumisega. See on iseloomulikult eepiline algus, mis teisiti sõnastatuna on tuttav setu jutustavatest lauludest. Erinevalt viimastest on vepsa loitsude algused rõhutatult religioossed - kõik, mida tehakse, 
tehakse õnnistades. Puhuti alustatakse loitsu venekeelse kristliku vormeliga:

\author{
Gospodi Bože, blagoslovi Hristos \\ Nuuzen homencou blaslovas, \\ pezemoi blaslovas, \\ sobimoitan blaslovas, \\ riśtimoi blaslovas \\ mänen uksess ukshe, \\ verajass verajaha \\ [Issand Jumal, onnnista Kristus \\ tõusen hommikul õnnistusega, \\ pesen ennast õnnistusega \\ riietun õnnistusega, \\ teen ristimärgi õnnistusega, \\ lähen uksest ukseni, \\ välisuksest välisukseni]
}

Püsivate elementide hulka kuulub ka teekonna algus:

Mänen lagedahe pü̈̈dho

vihandaha nurmhe

[lähen lagedale põllule,

haljale nurmele]

Lageda välja kujund taas on tuttav vene eepilistest lauludest (bõliinadest).

Edasine erineb juba loitsuti vastavalt haigusele, mida sellega kõrvaldatakse või hävitatakse. Algusmotiivi puhul ei paista loitsu objektil tähtsust olevat, olgu selleks prizor, purend, tulläižnena vm, kokkulangevused ja varieerumised sõltuvad teadjast, st ühe teadja erinevad loitsud on algusosas peaaegu identsed.

Loitsu edasine kulg meenutab ülesehituselt ahellaule: lagedal põllul on mingi objekt (kuldne või valge kivi, raudne tamm, kuldne voodi jne), sellel teine, teisel kolmas - kuni lõpuks tipneb kõik üleloomulike abistajate või abivahenditega. Üleloomulikud abistajad võitlevad nimetatud haiguse vastu relvadega (kolm meest hobustel), küüntega ja hammastega (must kass), küüntega ja nokaga (kuldne kukk). Kui ahela lõpplüliks on abivahend, näiteks kuldne sulg või nelikümmend võtit, siis sellega/nendega toimetab loitsija ise.

Haiguse kaotamist-hävitamist tähistavas osas esineb sageli loend. Näiteks prizora vastu suunatud loitsu kuulub loetelu erinevat värvi silmadest, mille vaade kacund on võinud kaetuse põhjustada, kuigi 
eelnevalt oli ometi välja selgitatud konkreetne isik, keda peeti pahategijaks, ning sellel olid konkreetset värvi silmad.

Loitsus purenda arstimiseks võidakse loetleda inimese kehaosi, mida haigus on kahjustanud või võib kahjustada jne. Loitsu lõppu kuulub (kui seda pole tehtud juba varem, seoses parandava tegevuse kirjeldusega) arstitava jumalasulase nime nimetamine ja kinnitus amin.

Ülejäänud jutustavad loitsud ei võimalda kindlate struktuuritüüpide väljatoomist. Arvuliselt on neist kõige rohkem fikseeritud ussisõnu, mille püsivamaks elemendiks võib pidada erinevat värvi madude loetelu. Varianditi võib neis kohata algriimilisi sõnapaare. Viimaseid tuleb ette ka muudes loitsudes. Üldiselt jätavad loitsudes leiduvad algriimid pigem juhusliku mulje, erinevalt näiteks vepsa itkude taotluslikust algriimist.

\section{Maagiline akadeemiline meditsiin}

Vepslased on väga kaua elanud oma traditsioonidesse juurduvat elu, aga ometi mitte muust maailmast sedavõrd äralõigatult, et uuemad nähtused poleks nende maailmapilti üldse mõjutanud. Uue ja vana kõrvuti toimimine või isegi kokkusulamine on võtnud väga vahelduvaid vorme, mis muudab vepsa rahvameditsiini uurimise iseäranis põnevaks.

Nagu öeldud, polnud minu 20. sajandi viimasel veerandil ja 21. sajandi alguses kohatud vepslaste tervis kiita. Muidugi olid mu vestluskaaslased enamasti vanad inimesed, aga jutus on välja tulnud ka nooremate ja isegi laste surmad - näiteks naistel rasedus- või sünnituskomplikatsioonide tõttu või lastel (imikutest kuni mõneaastaseni) seletamatuks jäänud järkjärguline hääbumine - ja seda aegadel, mil nälg oli jäänud minevikku ja arstiabi kättesaadav. Sellised juhtumid on kõige traditsioonitruumate seas kinnitanud seisukohta, et pole mõtetki bolnicas venuda (haiglas lamada). Samas on ometi teatavaks võetud haiguste uusi põhjuseid ja vastavaid raviviise.

Üks kõige üldisemaid kuuldud kaebusi on olnud, et pän kibištab (pea valutab) - ja sel juhul lisatakse sageli ka põhjus: davlenie. See on venekeelne sõna, mis tähendab rõhku ja mille all vepslased mõtlevad mitte õhurõhku ega vererõhku üldiselt, vaid konkreetselt kõrgvererõhutõbe. 
Davĺenie paistab olevat saanud paljude hädade kõige sagedasemaks põhjuseks. Peavalu kõrval on nimetatud ka mälu nõrgenemist - pä ii rada; en mušta nimida (pea ei tööta, ma ei mäleta midagi) - ning üldist halba enesetunnet ja jõuetust. Tundub, et davlenie on hakanud osalt hõivama kurja silma või nõiduse positsiooni esmase haigusseletusena. Selle üle kurdetakse, kuid seda ka ravitakse. Nagu on uueaegne haiguse nimetus, nii on uus ka ravi: davlenie ja tedai / noid ei kuulu ühte paradigmasse. Abinõuks davlenie vastu on olnud kõige tavalisemalt bolnitsahe ukoloile kävelda (käia haiglas süstimas). Alternatiiviks on kodus tabletkoid joda (tablette võtta).

Päris mitmel korral - esimesel vestluskaaslase algatusel, paaril järgmisel juba minu soovil - olen näinud neid mingisse suuremasse karpi koondatud koduapteeke, mis äratasid minus sügavat õudu, mitte vähem kui nõiakott. Need sisaldasid aastakümnete jooksul kogunenud paljusid erinevate tablettide karpe, suur osa ammu tähtaja ületanud, pudelikesi ja võidetuube, samuti tugevasti iganenud, ja lõpuks veel ilma mingite pakendite ja kirjadeta tablette ning kapsleid lahtiselt kõige vahel. Võib kindel olla, et kui selliste tablettide võtmine tõigi leevendust, siis üksnes tänu platseebo-efektile. Samahästi on huupi võetud tabletid võinud ka davlenie-ilminguid tugevdada.

Selge on kummatigi, et ametlik meditsiin on saavutanud kindla koha vepslaste elus ja sellesse suhtutakse lugupidavalt. Mingil määral on uus teadususk kahtlemata ahendanud rahvameditsiini autoriteeti. Nii olen sageli kuulnud väiteid, et enam pole selliseid teadjaid nagu vanasti, või on jutustaja kinnitanud, et nad pole olnud nõidarstidest ja nende ravivõtetest huvitatud ega tea neist midagi. Muidugi võib selliseidki kinnitusi võtta mitut pidi. Kui niimoodi on väitnud inimesed, kes teistelt kuuldu põhjal on ise praktiseerivad nõiad, siis on tegemist enesekaitsetaktikaga. Mõned, kes on vestluse algul deklareerinud mittemidagiteadmist, on jutu edenedes meenutanud nii mõndagi enda kogetut. Aga muidugi leidub neidki, kes küll midagi või isegi palju teavad, nagu see on vepslaste seas lausa vältimatu, kuid kes ühel või teisel põhjusel tahavad sellest kõigest distantseeruda. Üks põhjustest on kahtlemata ambivalentne suhtumine teadjatesse.

Arvesse tuleb ka modernses maailmas teadust ümbritsev aupaiste. Selle mõjul on rahvausundi arusaamu hakatud rüütama moodsamasse, värskelt autoriteetsuse saavutanud vormi ja neid niimoodi sanktsioneerima. 
Kooskõlas selle suundumusega seletas näiteks Vidlas elav kirjaoskamatu, väga laialt tuntud teadja T. J., kellest oli juttu seoses loitsudega (vt temast ja ta teadmistest moodsa elu kohta ka Arukask 2009) oma ravijavõimeid geenidega. Mida ta võis ise seda võõrast ja moodsat sõna kasutades mõelda? Küllap seda, et ta võimed olid kaasasündinud, mitte omandatud ega õpetatud. See tundub loogiline, kui mõelda tema jutustatud loole oma esimesest võiks küll öelda imeteost. Ta oli alles väikelapseeas, kolme-nelja aastane, kui aitas õnnelikult maha saada naabrinaisel, kes oli pikalt vaevelnud sünnitusvaludes ja vahepeal astunud naabrite juurde oma häda kurtma. T. oli haaranud naise kõhust ja ütelnud: Ĺähte sigapei! (tule sealt välja) - ning naine oligi kohe sünnitanud. Tavaliselt antakse arstimissõnad üle täiskasvanule või vähemalt selles eas lapsele, kes asjast aru saab. Antud juhtumil ei olnud keegi T.-d õpetada saanud ega püüdnudki, kõik sündis spontaanselt. Niisugune tulemuslik sünnitusabi on tavatu mitmes mõttes. Kõhust haaramise mõju võiks seletada käte erilise maagilise väega, mille pärast T. oli kuulus edaspidigi, aga eirata ei saa ka sellega liitunud lühikest vormelit. Tuleb välja, et väikelaps andis käsu lootele.

Moodsad terminid on võinud tungida isegi loitsudesse. Ühe ebamääraste sümptomitega, muuhulgas peavaluna avalduva tuulest tulnud haiguse tullïizžnena (tuulenina) parandamiseks kasutatud loitsu ilmselt improviseeritud lõpus on nimetatud ka, et pannakse paika haige närvid (stanovime $i$ azotame hänen nervad). Muide, tuulest tulnud haiguse ravimiseks on kasutatud ka haige ülevalamist veega läbi tuulepesa, mille vepsakeelne nimetus on tulliipeza.

Ilmekaid näiteid teadususust olen kohanud ka väljaspool meditsiini. Uskumus, et äikesetulekahju saab kustutada mitte vee, vaid piimaga, on vepslastel traditsiooniline, samuti kui naaberrahvastel, muuseas venelastel. Ometi väitis hea pärimusetundja, muinasjutuvestja ja sealjuures esimese põlvkonna vepslasest kooliõpetaja tütar L. Z. selle soovituse pärinevat ajakirjast Nauka $i$ Žizn. Ta ise oli kustutanud süttinud televiisori, paisates selle peale kolmeliitrilise purgitäie piima. Salapärane tundmatus keeles või muul viisil erakordne tarkuseraamat on tänapäevaks asendunud konkreetse populaarteadusliku ajakirjaga. 


\section{Lugu ja lõppsõna}

Jutustaja A. S., kes ise töötas meenutatud juhtumi ajal Pecoilas velskrina ja kuulus seega ametliku või akadeemilise meditsiini poolele, oli nii tõsiselt haigestunud, et ei saanud enam jalgu alla. Ta palus abi enda teada kõige tugevamalt teadjalt, kelle õpetuse järgi käis metsas andeks palumas. Selleks tuli kummardada ja pöörduda kõige metsas oleva poole, loetledes kaik mechaižed, kaik linduižed, hiinaižed, ojaižed, kalaižed - prostkate rababožijad Annad (kõik puud, kõik linnud, rohud, ojad, kalad, andke andeks jumalaümmardajale Annale). Samuti soovitas teadja kodus sauna juures andeks paluda sealsetelt isandatelt-emandatelt, st haldjatelt. Jutustaja meenutuse järgi hakkas tal pärast andekspalumisi küll parem, kuid ta otsustas ometi - ja siin on ilmselt tegu sisemise vastuoluga tema kui traditsioonikandja ja kui ametliku meditsiini professionaali vahel - haiglasse minna. Seal olles läks ta tervis uuesti halvemaks. Samas haiglas viibiv Mägäŕve külast pärit teadja märkas jutustaja tervise halvenemist ja ütles, et sel viisil (st ametliku meditsiini vahenditega, mille poole ta ometi ka ise oli pöördunud) pole paranemist lootagi. Ta katsuvat ise midagi teha, kuigi olevat kõik oma sõnad ära andnud ning hambaidki pole enam suus. Mägäŕvest pärit teadja tegi oma ravivaid veeprotseduure kolmel keskööl, kasutades sealjuures neidsamu sõnu, mida oli soovitanud eelmine teadja. Tähelepanuväärselt rõhutanud aga Mägäŕve teadja, et puude hulgast tuleb haab nimetamata jätta. Haab on paljude rahvaste (ka vepslaste) uskumustes olnud paha mainega puu. Irina Vinokurova järgi on vepslased nagu venelasedki uskunud, et Jeesuse reetja Juudas poos ennast üles haava otsa (Vinokurova 2005: 151). Meenutagem aga, et juba eesti regivärsilises ballaadis "Maie laul" neab Mai haaba, kes talle ei pakkunud varju, kusjuures seda saab vaevalt seletada kristluse mõjuga. Pigem võiks arvata, et seostamine Jeesuse ja tema reetjaga püüab juba olemasolevale pahale mainele anda rahvakristlikku põhjendust.

Nende parandamisseansside järele saigi jutustaja terveks. Ka Mägäŕve külast pärit teadja lahkus pärast seda haiglast, ootamata arstipoolset väljakirjutamist.

Toodud lugu lükkab parimal viisil ümber põhjenduse rahvameditsiinist kui puuduva akadeemilise meditsiini paratamatust alternatiivist (ende ved́ boĺnicaid iilend). Näeme, kuidas rahvaarsti poole võis pöörduda ka meditsiinitöötaja ja kuidas haigla võis olla lausa rahvamedit- 


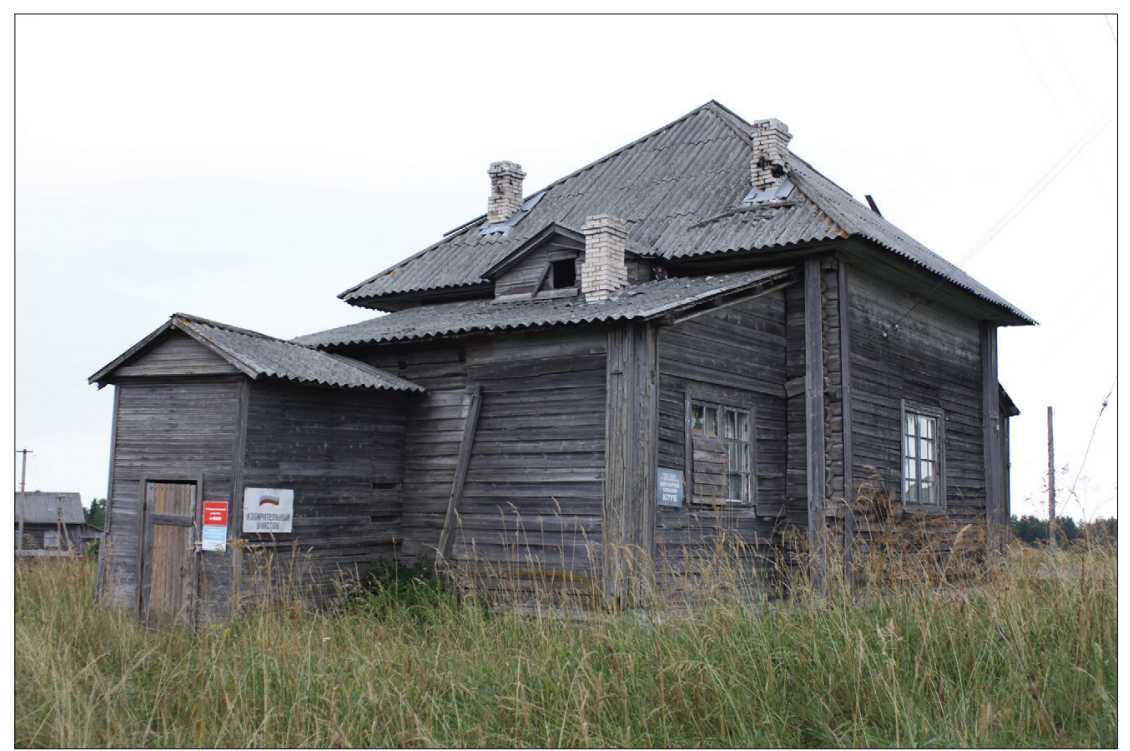

Foto 5. Mägärve kunagine kirik. Indrek Jäätsi foto 2010.

siini praktiseerimise paigaks. Muidugi on sellega kaasnenud inimese erinevate rollide (meditsiinitöötajast patsient, patsiendist tervendaja) tähelepanuväärne segunemine.

Lõpuks leiab toodud juhtumi puhul kinnitust vepsa rahvameditsiini elujõud 20. sajandi lõpul ja 21. sajandi alguses kogu oma tugeva usundilise aluse ja sõnakesksusega.

Kaik (kõik), nagu kõlab paljude vepsa muinasjuttude helisalvestuste lõpusõna. 


\section{Kirjandus}

Arukask, Madis 2009. Kesk-Vepsa teadjaga vesteldes: erinevad maailmapildid ja rollid. Annuk, Eve (koost ja toim). Paar sammukest. Eesti Kirjandusmuuseumi aastaraamat XXV. Tartu: Eesti Kirjandusmuuseumi Teaduskirjastus, lk 122-145.

Balikiene, Monika 2012. Representation of the Evil Eye Belief in Contemporary Lithuania. Summary of doctoral dissertation. Kaunas: Lithuanian Academic Libraries Network.

Hakamies, Pekka 1994. Vepsäläisten suullisesta perinteestä. Heikkinen, Kaija \& Mullonen, Irma (toim). Vepsäläiset tutuksi. Kirjoituksia vepsäläisten kulttuurista. Karjalan tutkimuslaitoksen julkaisuja 108. Joensuu: Joensuun yliopisto, lk 73-86.

Heikkinen, Kaija 2006. Metsänpelko ja tietäjänaiset. Vepsäläisnaisten uskonto Venäjällä. Helsinki: Suomalaisen Kirjallisuuden Seura.

Iljina, Irina 2008. Põhja piirkondlik traditsioon komide rahvameditsiinis. Mäetagused 39, lk 75-92 (doi: 10.7592/MT2008.39.iljina).

Joalaid, Marje 2000. Itk vepsa matusekombestikus. Salve, Kristi \& Kõiva, Mare \& Tedre, Ülo (toim). Tagasipöördumatus. Sõnad ja hääl. Tartu: Eesti Kirjandusmuuseumi folkloristika osakond, lk 265-282.

Kettunen, Lauri 1943. Vepsän murteiden lauseopillinen tutkimus. SUSTL XXXVI. Helsinki: Suomalais-Ugrilainen Seura.

Kohler, Vilja 2012. Rästikuviin püsib rahvameditsiinis. Tartu Postimees, 23.08 (http://www.tartupostimees.ee/948200/rastikuviin-pusibrahvameditsiinis - 14. juuni 2013). [Samal päeval ilmus eelviidatu põhjal Õhtulehe võrguväljaandes lühendatud versioon.]

Kõiva 2011a = Койва, Маре. Колдовские, магические и заговорные книги в эстонском фольклоре. Научно-публииистический журнал "Центр u периферия" 3. Научно-исследовательского института гуманитарных наук при Правительстве Республики Мордовии, lk 69-75.

Kõiva, Mare 2011b. Eesti loitsud. Tallinn: Pegasus.

Kõivupuu, Marju 2000. Rahvaarstid Võrumaalt: noor ja vana Suri Hargla kihelkonnas. Tartu: Võro Instituut. 
Loginov 1993 = Логинов, К. К. Селейные обряды и верования русских Заонежья. Петрозаводск: Карельский наычный центр РАН.

Makarjev, S. 1931. Vepsäläiset. Lyhyt kansatieteellinen kuvaus. Leningrad: Kirja.

Mullonen, Irma 1994. Paikannimistö vepsäläisten henkisen perinteen valottajana. Heikkinen, Kaija \& Mullonen, Irma (toim). Vepsäläiset tutuiksi. Kirjoituksia vepsäläisten kulttuurista. Joensuu: Joensuun yliopisto, lk 63-72 [käesolevas kogumikus lk 227-236].

Pentikäinen, Juha 1971. Marina Takalon uskonto. Uskontoantropologinen tutkimus. Helsinki: Suomalaisen Kirjallisuuden Seura.

Pulkin 1985 = Пулькин, В. А. Глубокие водь Корбярви. Ленинград: Лениздать.

Rainio, Jussi 1973. Vanhaa äänisvepsäläistä lääkintätietoa. Sihvo, Hannes \& Kaukonen, Väinö (toim). Karjala. Idän ja lännen silta. Kalevalaseuran vuosikirja 53. Porvoo: Werner Söderström OY, lk 289-312.

Raud, Piret 1975. Loodus Djorža karjalaste rahvameditsiinis. Eesti Loodus 9, lk 519-521.

Raudalainen, Taisto-Kalevi 2008. Lääne- ja Kesk-Ingeri ravitsemisjutud: esituskontekst, motiivid, toimingud. Kalmre, Eda \& Västrik, Ergo-Hart (koost). Kes kõlbab, seda kõneldakse. Pühendusteos Mall Hiiemäele. Tartu: Eesti Kirjandusmuuseumi Teaduskirjastus, lk 169-215.

Salve, Kristi 1995. Forest Fairies in the Vepsian Folk Tradition. Kõiva, Mare \& Vassiljeva, Kai (toim). Folk Belief Today. Tartu: Eesti Teaduste Akadeemia Keele ja Kirjanduse Instituut \& Eesti Kirjandusmuuseum, lk 413-434.

Salve, Kristi 2005. Vepsäläisestä folkloresta. Saressalo, Lassi (toim). Vepsä. Maa, kansa ja kulttuuri. Suomalaisen Kirjallisuuden Seuran Toimituksia 1005 \& \& Tampereen Museoiden Julkaisuja 81. Tampere: Tampereen museot \& Helsinki: Suomalaisen Kirjallisuuden Seura, lk 86-115.

Semakova \& Rogozina 2006 = Семакова, И. Б. \& Рогозина, В. В. Материалы по традиционной медицине вепсов (мифологический аспект). Богданов, Н. И. \& Винокурова, И. Ю. (koost). Современная наука о вепсах: достижения u перспективы. Петрозаводск: Российская академия наук. Карельский научный центр, lk 302-314. 
Setälä, Eemil Nestor \& Kala, J. H. 1951. Näytteitä äänis- ja keskivepsän murteista. Julkaissut ja suomentanud E. A. Tunkelo, apunaan R. Peltola. SUST 100. Helsinki: Suomalais-Ugrilainen Seura.

SOS = Елисеев, Ю. С. \& Зайцев, Н. Г. (toim) 2007. Сопоставительнооноласиологический словарь диалектов карельского, вепсского, саалского языков. Петрозаводск: КарНЦ РАН (http://bookre.org/ reader?file $=803574 \& p g=0-16$. juuni 2013).

Sõukand, Renata \& Kalle, Raivo. HERBA. Eesti rahvameditsiini ravimtaimede andmebaas (http://www.folklore.ee/herba - 16. juuni 2013).

Zaitseva \& Mullonen 1969 = Зайцева, М. И. \& Муллонен, М. И. Образиьь вепсской речи. Ленинград: Наука.

Zaitseva, Maria \& Mullonen, Maria 1972 = Зайцева, М. И. \& Муллонен, М. И. Словарь вепсского языка. Ленинград: Наука.

Turunen, Aimo 1952. Über die Volksdichtung und Mythologie der Wepsen. Studia Fennica VI. Helsinki: Suomalaisen Kirjallisuuden Seura.

Tupits [Goršič], Ave 2009. Käsitlusi rahvameditsiinist: mõiste kujunemine, kogumis- ja uurimistöö kulg. Dissertationes folkloristicae universitatis Tartuensis. Tartu: Tartu Ülikooli Kirjastus (http://rahvatervis.ut.ee/ bitstream/1/4301/1/Ave\%20Tupits-rmtk.pdf - 14. juuni 2013).

Vinokurova, Irina 2005. Vepsäläisten mytologis-uskonnollisista käsityksistä. Saressalo, Lassi (toim). Vepsä. Maa, kansa ja kulttuuri. Helsinki: Suomalaisen Kirjallisuuden Seura \& Tampere: Tampereen museot, lk 136-151.

Vinokurova 2006 = Винокурова, И. Ю. Животнье в традиционном мировоззрении вепсов (опьт реконструкиии). Петрозаводск: ПетрГУ. 


\title{
Summary
}

\section{Some aspects of Vepsian folk medicine}

\author{
Kristi Salve
}

Keywords: charms, folk belief, folk medicine, healers, medicinal herbs, rational and magical, Vepsians

The article is based, for the most part, on the materials that the author has collected during decades of fieldwork. Additionally, she has used publications mainly concerned with linguistics: above all, collections of texts, but also researches and dictionaries. Source material has even been obtained from fiction. The author has also made use of scholarly sources dedicated to folk medicine; unfortunately, there are only few about Vepsians, yet researches about other peoples also offer good material for comparison.

One of the central ideas of the article is the great vitality that Vepsian folk medicine demonstrated even at the end of the 20th century. Although the fact that people seeking help have turned to healers has often been explained by the absence of hospitals in olden times, such allegations are rather born out of caution: no-one wants to show to strangers that Vepsians are backward, uneducated, etc., as has been estimated by the official discourse. In fact, it is not only the elderly that turn to healers for help, but also their children and grandchildren, when they come to visit for holidays.

In the second half of the 20th century, relations between folk medicine and academic medicine in Vepsian villages were interesting. Generally, the spheres of activity were shared rather peacefully. Those who used the help of healers did not oppose the latter to academic medicine. In rare cases when it happened, it was rather folk medicine that was considered more efficient. Yet, the most recent generations have accepted help from medical workers (mainly intermediate level) gratefully and without criticism. For older generations, injections and administering pills are kind of magic activities.

Besides stating the vitality of Vepsian folk medicine, the article also pays attention to the division of curing methods into rational and magical, which has often been used by ethnologists-folklorists. This kind of division seems to be of doubtful productivity. Highlighting herb treatment, massage, etc. is ideologically substantiated, whereas tradition bearers specifically bring to the fore charms, prayers, holy water, and other similar methods clearly based on beliefs. This is related to the fact that the aetiology of diseases has a predominantly religious background. 
It could be presumed that until the Vepsian village (with currently predominantly retired inhabitants) is alive, folk medicine and healers still serve their function there. As was the case with the 20th century, certain changes also occur in the 21st century, and the observation of these changes would also be necessary in the future. 


\section{Uurimusi vepsa rahvausust}

Koostaja ja toimetaja Madis Arukask

http://www.folklore.ee/rl/pubte/ee/sator/sator16/

ISSN 1736-0323 (veebiväljaanne)

ISBN 978-9949-544-96-7 (veebiväljaanne)

ISSN 1404-2011 (trükis)

ISBN 978-9949-544-95-0 (trükis)

DOI: 10.7592/Sator.2016.16

Tartu 2016

Sarja toimetaja: Mare Kõiva

Koostaja ja toimetaja: Madis Arukask

Keeletoimetaja: Asta Niinemets

Kaas ja kujundus: Andres Kuperjanov

Kaanefoto: Madis Arukask

Küljendus: Diana Kahre

HTML: Diana Kahre

Trükis ilmunud: Uurimusi vepsa rahvausust.

Koostaja ja toimetaja Madis Arukask. SATOR 16. Tartu 2016

Raamatu ettevalmistamist ja väljaandmist on toetanud Eesti Teadusagentuur (grandid nr 7385 ja 9271) ning Eesti Vabariigi Haridus- ja Teadusministeerium (projekt IUT 2-43). Raamatu toimetamist ja vormindamist toetas Euroopa Liit Euroopa Regionaalarengu Fondi kaudu (Eesti-uuringute Tippkeskus), see on seotud Eesti Teadusagentuuri institutsionaalse uurimisprojektiga IUT 22-5. Trükitud Eesti Kultuurkapitali toetusel.

E-raamatu valmimist toetas: EKKM14-344 Eesti keele, kultuuri ja folkloori kasutusalade laiendamine ja tutvustamine elektroonilistel infokandjatel.

(C) 2016 EKM Teaduskirjastus

(C) 2016 Eesti Folkloori Instituut

() 2016 EKM FO rahvausundi ja meedia töörühm

(C) 2016 autorid 